Vilaça, R., Soares, I., Osório, M. y Gil, F. (2018): “Cerâmicas pintadas de 'tipo Carambolo' na Beira interior (centro de Portugal)", Spal 27.2: 55-88. DOI: http://dx.doi.org/10.12795/spal.2018i27.16

\title{
CERÂMICAS PINTADAS DE “TIPO CARAMBOLO” NA BEIRA INTERIOR (CENTRO DE PORTUGAL)
}

\section{PAINTED CERAMICS OF “CARAMBOLO TYPE” IN BEIRA INTERIOR (PORTUGAL)}

\author{
RAQUEL VILAÇA \\ Instituto de Arqueologia. Faculdade de Letras da Universidade de Coimbra. \\ Centro de Estudos em Arqueologia, Artes e Ciências do Património. \\ Correo-e: rvilaca@fl.uc.pt ORCID: https://orcid.org/0000-0003-0019-7256 \\ INÊS SOARES \\ Mestre em Arqueologia e Território. Faculdade de Letras da Universidade de Coimbra. \\ Correo-e: srs_ns@hotmail.com. ORCID: https://orcid.org/0000-0003-4142-0389 \\ MARCOS OSÓRIO \\ Instituto de Arqueologia. Faculdade de Letras da Universidade de Coimbra. \\ Centro de Estudos em Arqueologia, Artes e Ciências do Património. Câmara Municipal do Sabugal. \\ Correo-e: arkmarcos@hotmail.com. ORCID: https://orcid.org/0000-0003-4340-4614 \\ FRANCISCO GIL \\ Centro de Física da Universidade de Coimbra. Grupo de Química-Física Molecular da Universidade de Coimbra. \\ Correo-e: fgil@fis.uc.pt. ORCID: https://orcid.org/0000-0001-7546-0288
}

Resumen: A partir de un pequeño conjunto de fragmentos cerámicos con decoración pintada, de tipo Carambolo, identificados en 5 yacimientos de la región de Beira Interior sometidos a excavaciones arqueológicas, los autores plantean varias consideraciones sobre el significado y las implicaciones culturales de esos materiales, poco usuales en la región. Se trata del primer estudio de fondo realizado en Portugal sobre este tipo de cerámicas, en el que se discuten, de forma exhaustiva, sus aspectos técnicos, morfológicos, decorativos y simbólicos. El análisis de la pigmentación de las cerámicas, por fluorescencia de rayos $\mathrm{X}$ (XRF), difracción de rayos X (XRD) y espectroscopia microRaman ( $\mu$-Raman), permite decir que está compuesta en su totalidad por ocre rojo. Con base en la integración de los datos y su articulación con fechas de 14Carbono, algunas inéditas, se propone que el encuadramiento cronológico de estas cerámicas remonte a los finales de la Edad del Bronce, aunque en determinados casos alcance la Primera Edad del Hierro. Se plantean algunas cuestiones relativas a la potencial producción local, o exógena, de estas cerámicas y su significado como expresión de contactos entre Andalucía y el Centro del territorio portugués.

\begin{abstract}
From a small set of ceramic fragments with Carambolo type painted decoration, identified in 5 settlements of the Beira Interior region, subject to archaeological interventions, the authors make several considerations about the meaning and cultural implications of these materials, uncommon in the region. This is the first substantive study carried out in Portugal on this type of ceramics, in which the technical, morphological, decorative and symbolic aspects are fully discussed. Ceramic pigmentation analysis by X-ray fluorescence (XRF), X-ray diffraction (XRD) and micro-Raman ( $\mu$-Raman) spectroscopy, allows to say that it is composed in its entirety by red ochre. Based on the integration of the data and its articulation with dates of 14Carbono, some unpublished, it is proposed that the chronological framing of these ceramics goes back to the Late Bronze Age, although in certain cases reaches the Early Iron Age. There are still some questions regarding the local or exogenous production of these ceramics and their significance as an expression of contacts between Andalusia and the Centre of Portuguese territory.
\end{abstract}


Palabras clave: Cerámicas de tipo Carambolo; Beira interior; Bronce Final / Primera Edad del Hierro; óxidos de hierro; contactos culturales.

\section{INTRODUÇÃO E ENQUADRAMENTO}

Conforme indica o título, este texto tem como objecto de estudo a cerâmica de tipo Carambolo e, como objectivo, pretende contribuir para o seu melhor conhecimento no Ocidente da Península Ibérica, em concreto no Centro do território português (Beira Interior).

As cerâmicas que designamos de "tipo Carambolo" correspondem a um número reduzido de pequenos fragmentos que ostentam a peculiar decoração pintada a vermelho. Essa classificação deve ser entendida em termos estritamente estilístico-decorativos, permanecendo em aberto a questão da sua origem de fabrico, assunto que, todavia, discutiremos adiante.

A região, definida a norte e a sul pelos dois grandes rios peninsulares que correm para o Atlântico ocidental, o Douro e o Tejo, respectivamente, tem como limite oriental a fronteira política que divide os dois países ibéricos e, a ocidente, encontra contornos mais indefinidos, primeiro, no Alto Mondego, depois no conjunto de serranias da Cordilheira Central (Estrela e Gardunha).

Trata-se, evidentemente, de uma região distante e marginal, na geografia e nas problemáticas específicas, da zona nuclear desse tipo de cerâmicas, centrada no Baixo Guadalquivir. Distante e marginal, mas não desconexa, uma vez que são diversos os elementos arqueológicos que autorizam abordagens articuladas entre ambas as regiões, nas quais a presença do Mediterrâneo se fez sentir, embora com intensidades e contornos culturais claramente distintos, entre finais do II milénio a. C. e os primeiros séculos do seguinte (Vilaça 2008b; 2013a).

Neste sentido, não cabe aqui qualquer discussão aprofundada sobre as questões inerentes a essa região andaluza nem, tão-pouco, uma análise global sobre esta categoria de cerâmica, que Carriazo denominou de "tipo Carambolo" ("classe 18") pelos surpreendentes achados efectuados no, então, considerado "fondo de cabaña" (nível IV) do sítio epónimo, também ele corporizando o que se supunha ser, na altura, «la representación más pura, más completa y más rica de la cultura tartesia» (Carriazo 1969: 340; 1973: 504). A cerâmica de tipo Carambolo foi, assim, e durante muito tempo, assumida como "fóssil-director" de Tartesso, perspectiva que hoje está longe de ser consensual e de que se fazem eco algumas das leituras mais recentes
Keywords: Carambolo type ceramics; Beira Interior; Late Bronze Age / Early Iron Age; iron oxides; cultural contacts.

e problematizantes sobre aquela entidade cultural cuja historiografia comporta abordagens arqueológicas, históricas e literárias (v.g. Campos e Alvar 2013).

O emblemático sítio de El Carambolo é também hoje uma outra realidade muito distinta daquela que se pensou inicialmente, como bem foi analisado em oportuna retrospectiva crítica (Escacena Carrasco 2010: 104-113), justamente por um dos investigadores que, recusando-lhe o estatuto de povoado, intuíra, antes das novidades inerentes às escavações de 2002-2005, a dimensão sagrada desta consagrada estação arqueológica, correspondendo o fundo de cabana a fossa ritual (Belén e Escacena 1997: 110-114). A narrativa dos responsáveis pelas escavações já deste milénio centra-se na ideia da existência de um santuário fenício expresso num complexo de estruturas arquitectónicas com remodelações sucessivas (v.g. Rodríguez Azougue e Fernández Flores 2005; Fernández Flores e Rodríguez Azogue 2007), narrativa que também mereceu recente crítica, concretamente no que diz respeito à suposta fundação ex novo do santuário (v.g. Torres Ortiz 2016).

Por outro lado, foram já elaboradas diversas sínteses sobre a forma como estas cerâmicas, também conhecidas como de "tipo Guadalquivir I" (Ruiz Mata 1984-1985), têm sido equacionadas pelos investigadores, seja sobre as origens, características ou cronologias, sínteses essas (v.g. Amores 1995; Torres Ortiz 2002: 130-135; Casado Ariza 2003) que nos servirão de guia ao longo deste texto, pelo que também nos dispensamos de discorrer sobre esse aspecto mais historiográfico deste peculiar tipo cerâmico. Sublinhe-se ainda que, muito recentemente, foi publicada obra de maior fôlego relativa ao conjunto cerâmico de El Carambolo, onde se sistematizam e aprofundam determinados aspectos da cerâmica de tipo Carambolo, a que também atenderemos (Casado Ariza 2015).

Este tipo cerâmico, identificado pela primeira vez em 1945 em Mesas de Asta (Torres Ortiz 2002: 130), só cerca de cinquenta anos depois viria a ser registado no Centro do território português, na Moreirinha. Na altura, e ainda durante algum tempo, este constituiu um caso isolado na Beira Interior, conhecendo-se na época, para o território português, apenas mais alguns registos circunscritos ao Alentejo (Vilaça 1995: 300301 e fig. 41). 


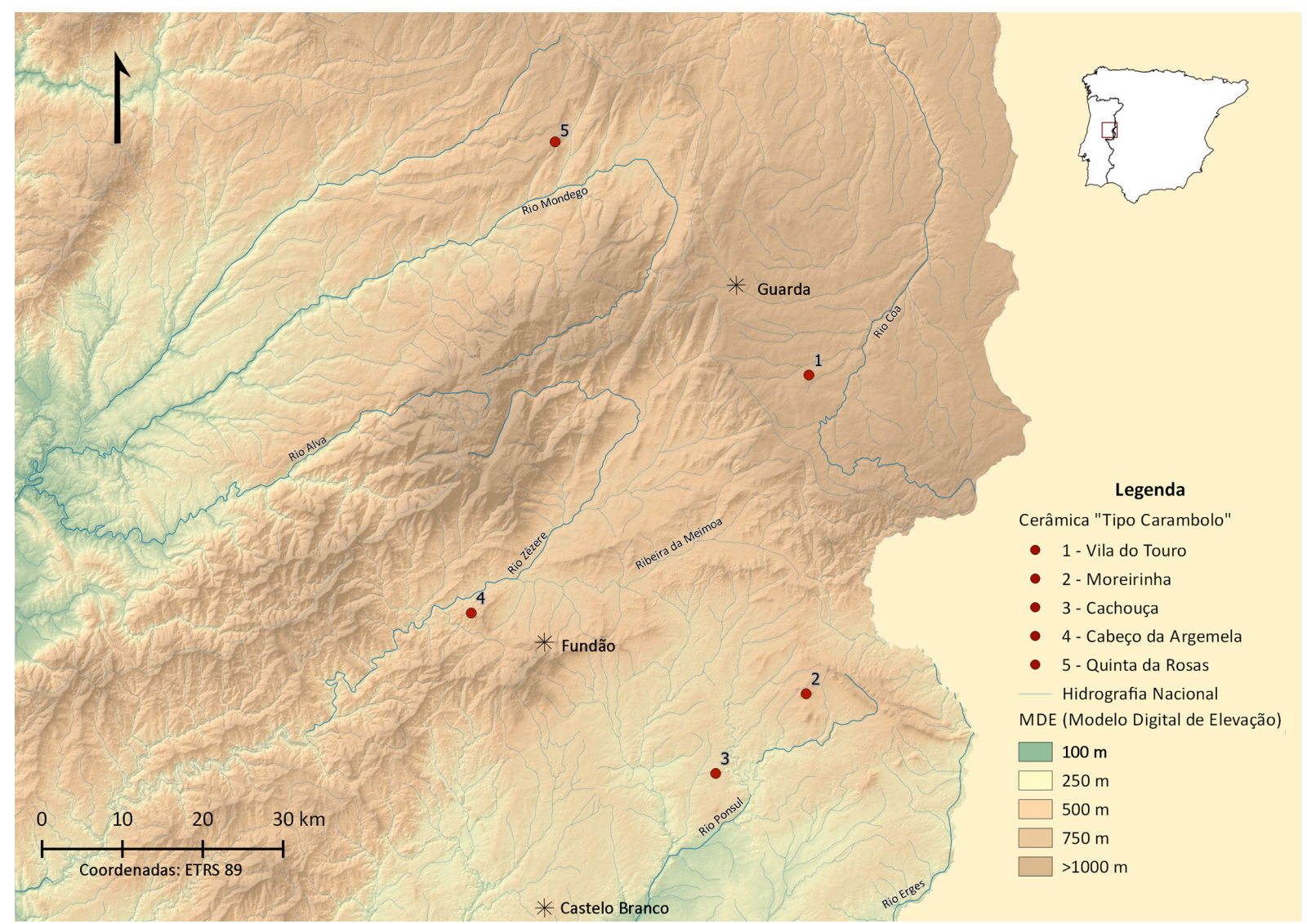

Figura 1. Distribuição dos sítios com cerâmica de tipo Carambolo na Beira Interior.

A situação é hoje diferente, uma vez que se multiplicaram os achados deste tipo de cerâmica, se bem que manifestando-se sempre em diminuta quantidade, tanto no sul de Portugal, concretamente no Alentejo, como na Beira Interior. Neste caso, o número de fragmentos não só aumentou na Moreirinha, mercê de duas breves campanhas aí realizadas, respectivamente em 1995 e 1996, como se ampliou o número de sítios com registo de cerâmicas de tipo Carambolo, alargando, inclusive, a mancha de dispersão a zonas mais setentrionais e ocidentais daquela região (fig. 1). Também no primeiro caso a cartografia das cerâmicas de tipo Carambolo viu-se, entretanto, enriquecida com novos achados nas regiões de Évora, Alandroal, Serpa, Moura, Beja e Mértola, resultantes, sobretudo, de intervenções desenvolvidas no âmbito da "arqueologia de salvamento".

A notícia e divulgação de alguns dos achados foi sendo feita nos últimos anos em textos de carácter geral sobre o povoamento do Bronze Final e Ferro Inicial, como se indicará caso a caso. Todavia, a importância dessas cerâmicas, nunca analisadas com o pormenor necessário e a revelação, muito recentemente (20142016), de um novo conjunto em Vila do Touro (Sabugal), justifica este estudo integrado, no qual se procurará valorizar esses materiais nos seus aspectos técnicos, morfológicos e decorativos, bem como nas vertentes cronológica e contextual. Serão também desenvolvidas algumas considerações sobre os potenciais significados da sua ocorrência nos respectivos contextos de achado, seja em termos simbólicos, seja como expressão de contactos entre o Centro Ocidental interior e o Sul peninsulares.

\section{SÍTIOS, CONTEXTOS E CRONOLOGIAS}

As cerâmicas de tipo Carambolo da Beira Interior são provenientes de cinco povoados: Moreirinha (Idanha-a-Nova, Castelo Branco), Cachouça (Idanha-a-Nova, Castelo Branco), Cabeço da Argemela (Fundão, Castelo Branco), Vila do Touro (Sabugal, Guarda) e Quinta das Rosas (Fornos de Algodres, Guarda), cujas escavações foram desenvolvidas no âmbito de distintos 
projectos de investigação concluídos. Em curso, encontram-se as escavações em Vila do Touro, inscritas no projecto de requalificação do respectivo castelo, numa colaboração entre a Câmara Municipal do Sabugal e a Universidade de Coimbra. Na sua esmagadora maioria todas elas resultam de contextos estratigráficos conhecidos, aspecto de relevar uma vez que um dos problemas inerentes a esta categoria de cerâmicas é, justamente, o da sua cronologia.

\subsection{Moreirinha}

Trata-se do primeiro local que revelou cerâmica deste tipo. A Moreirinha é um sítio de altura, de notável impacto físico, com um controlo visual de longo alcance em quase todos os sentidos (fig. 1-2). A plataforma mais elevada, que atinge a altitude de $679 \mathrm{~m}$, foi ocupada em finais do II milénio a.C. e inícios do seguinte, tendo-se conservado diversas estruturas habitacionais de base pétrea, como cabanas, alinhamentos murários, lareiras, pisos, etc. (Vilaça 1995). As intervenções posteriores, que ampliaram a escavação nesta área, confirmaram a existência de um núcleo de cabanas subcirculares construídas em pedra, barro e madeira, de que restam as sapatas de base e alguns buracos de poste. Este último conjunto encontra-se em estudo, tendo merecido uma análise preliminar, e parcial, da construção das cabanas em trabalho académico (Soares 2016).

Também os materiais destas últimas intervenções, com destaque para as cerâmicas e metais, só parcialmente publicados, inscrevem-se na mesma linha cronológica e cultural dos já conhecidos (Vilaça 1995), onde pontuam, por exemplo, as cerâmicas de tipo Lapa do Fumo e de tipo Cogotas I, correspondendo os artefactos de bronze a argolas, braceletes, cinzéis, punhais, ponderal, etc., e os de ferro a pequenas lâminas de facas e serras, estando igualmente presente âmbar báltico (Vilaça 2013b; Vilaça et al. 2002). Os fragmentos de tipo Carambolo integram-se nestes contextos.

Existem quatro datas de ${ }^{14}$ Carbono relativas às camadas 2 e 3, interpretadas como camadas de uma única fase global de ocupação, todas elas obtidas a partir de madeira carbonizada (Vilaça 1995: 215, 236, 372 e segs.). As datas ICEN-835: 2910 \pm 45 BP

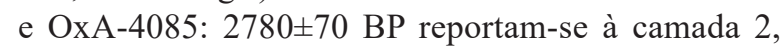
esta última datando directamente a lareira 2. As datas

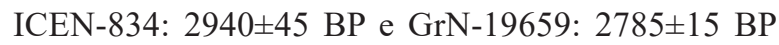
associam-se à camada 3 , do início da ocupação do povoado, mas culturalmente idêntica à ocupação representada na camada 2 .

\subsection{Cachouça}

$\mathrm{Na}$ mesma sub-região encontra-se a Cachouça (fig. 1-3). Trata-se agora de um sítio localizado no remate de um esporão, a $378 \mathrm{~m}$ de altitude, sobranceiro ao rio Torto, subsidiário do Ponsul. Encontra-se dissimulado na linha de relevos envolvente, embora o domínio visual, sobretudo para sul e nascente, se mantenha como tópico fundamental.

Profundamente revolvida por trabalhos de lavoura ao longo dos tempos, a estação conheceu ocupação em três fases principais: no Neolítico Final/ Calcolítico Inicial, no Bronze Final e na I Idade do Ferro. A primeira terá sido efémera (Vilaça 2008a: 161-162). Pelo contrário, entre os finais do II milénio a.C. e possivelmente o séc. VII a.C., no lugar, que não se confina a mero espaço habitacional atendendo a testemunhos vários de índole cultual/ ritual, foi construído um talude subcircular de terra e pedra delimitando área de c. $900 \mathrm{~m}^{2}$, com orientação NW-SE, com o qual se articulam outras estruturas, nomeadamente uma cabana, pisos de argila, lareiras, fossas (Vilaça 2007a). Alguns dos afloramentos graníticos, nas proximidades do talude, possuem diversas "fossettes", tal como dois dos monólitos que o incorporavam. Estruturas, artefactos específicos, monólitos e afloramentos, que devem também ser entendidos como 'arquitectura' do sítio, i.e. como elementos cénicos de um espaço construído e vivido, no qual terão decorrido diversas acções profundamente ritualizadas (Vilaça 2007a).

Neste sentido, a diversidade artefactual, entre cerâmicas e metais, sobretudo, deve ser igualmente sublinhada. Conectadas com a ocupação de finais da Idade do Bronze ou na transição para a Idade do Ferro, contam-se, entre outras, cerâmicas de ornatos brunidos de tipo Lapa do Fumo (variante sulcos e faixas) e cerâmicas decoradas com incisões finas executadas antes e após cozedura, estas na linha técnica e estilística das cerâmicas de tipo Baiões/ Santa Luzia. Entre os artefactos de bronze, o destaque vai para o espeto articulado de "tipo Alvaiázere", com ornamentação zoomórfica no punho. Admitindo-se que algumas daquelas cerâmicas poderão ter tido continuidade em inícios da I Idade do Ferro, nesta inscrevem-se, contudo, outras realidades artefactuais reveladoras de novos tempos, novos gostos e novos contactos, como as cerâmicas "a peine" de tipo mesetenho, as primeiras produções feitas ao torno, de matriz 'orientalizante', a manipulação (produção?) do ferro, o vidro, elementos coroplásticos, etc., em parte ainda inéditos (Vilaça 2007a; Vilaça e Basílio 2000).

As cerâmicas de tipo Carambolo foram recolhidas na zona Norte da estação e integravam-se em contextos 


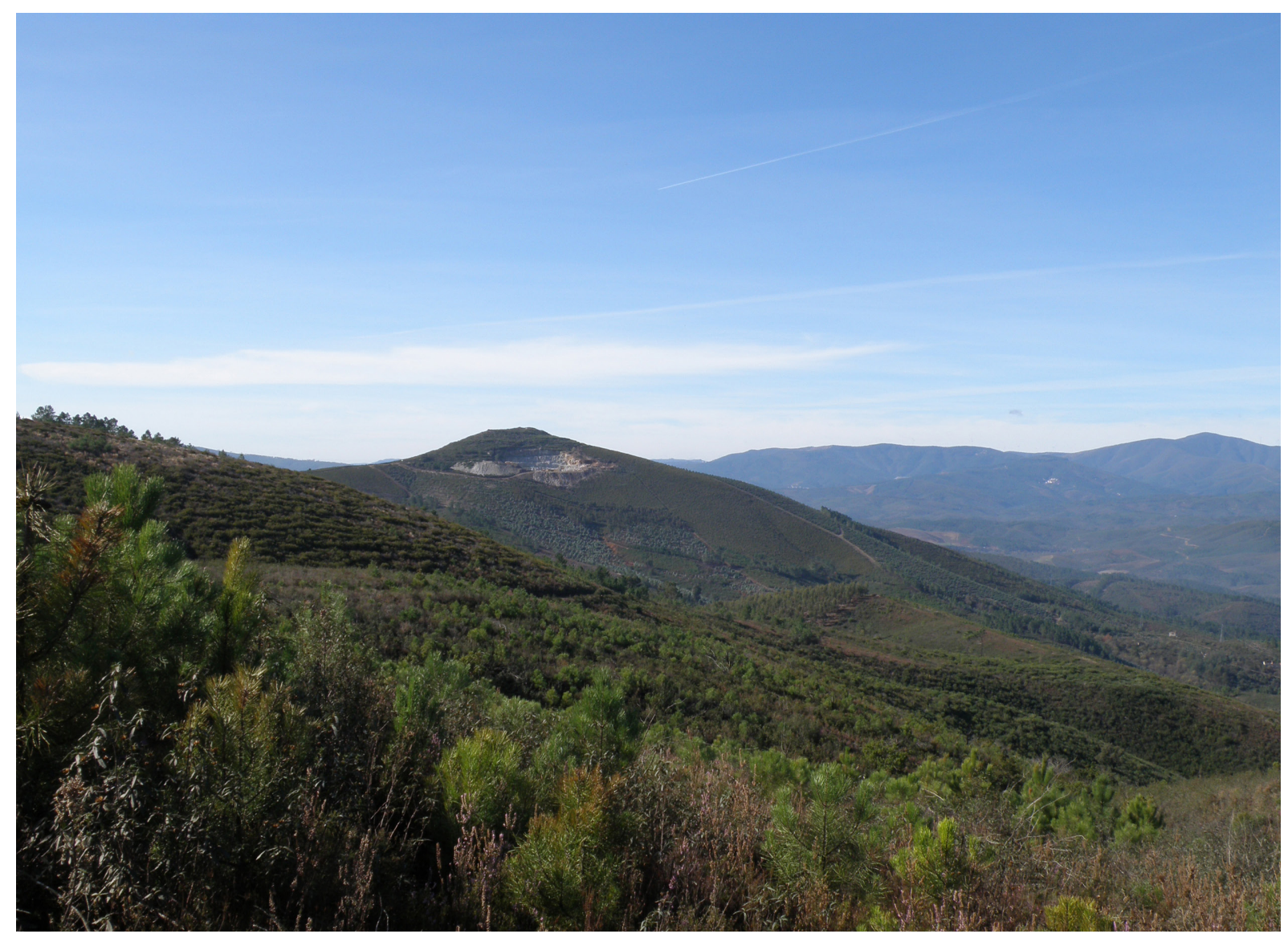

Figura 2. Cabeço da Argemela, observando-se, ao centro, a área de pedreira.

para os quais dispomos de três datas de 14Carbono, todas elas obtidas a partir de carvão.

A data CSIC-1286: 2998 33 BP é de I'15 03, que corresponde à camada de base, subjacente ao nível de construção do piso de terra batida de uma cabana subcircular. Essa camada reunia escassos e minúsculos fragmentos cerâmicos neolíticos muitos pequenos e rolados misturados com materiais reportáveis aos finais da Idade do Bronze (taças carenadas, fragmentos de bronze, uma pequena conta esférica em ouro). As datas Sac-1929: 2760 \pm 80 BP e Sac-1931: 2690 \pm 60 BP são de L'10/11 02 base, camada que correspondente à que se formou em momento imediatamente anterior à construção da cabana. Continha misturados materiais do Bronze Final (ou da sua tradição, como taças carenadas, algumas com ornatos brunidos, fragmentos de chapa de bronze rebitados) com outros já claramente reportáveis aos inícios da I Idade do Ferro (por exemplo, pequena faca de ferro afalcatada, cerâmica penteada típica da Meseta, cerâmicas a torno de âmbito 'orientalizante').

\subsection{Cabeço (ou Castro) da Argemela}

O terceiro local com cerâmica deste tipo é o Cabeço da Argemela (fig. 1-4). Corresponde a elevação de forma tendencialmente cónica, a $746 \mathrm{~m}$ de altitude, situada na serra do Gomes, no limite poente da Cova da Beira, região natural delimitada pelas serras da Estrela e da Gardunha (fig. 2). Mais uma vez, destaca-se a ampla visibilidade a partir do cabeço em relação ao espaço envolvente, com particular domínio sobre o rio Zêzere no sentido NE-SW.

O povoado possui duas linhas de muralha, uma definindo pequena acrópole e a segunda localizando-se a meia encosta, logo acima da pedreira que hoje consome este sítio arqueológico. Com efeito, desde inícios deste século, o povoado, e não obstante a sua importância científica e identitária como lugar de memorial colectivo das populações das aldeias vizinhas, tem sido alvo de destruição decorrente de trabalhos autorizados de exploração de uma pedreira, o que obrigou, 


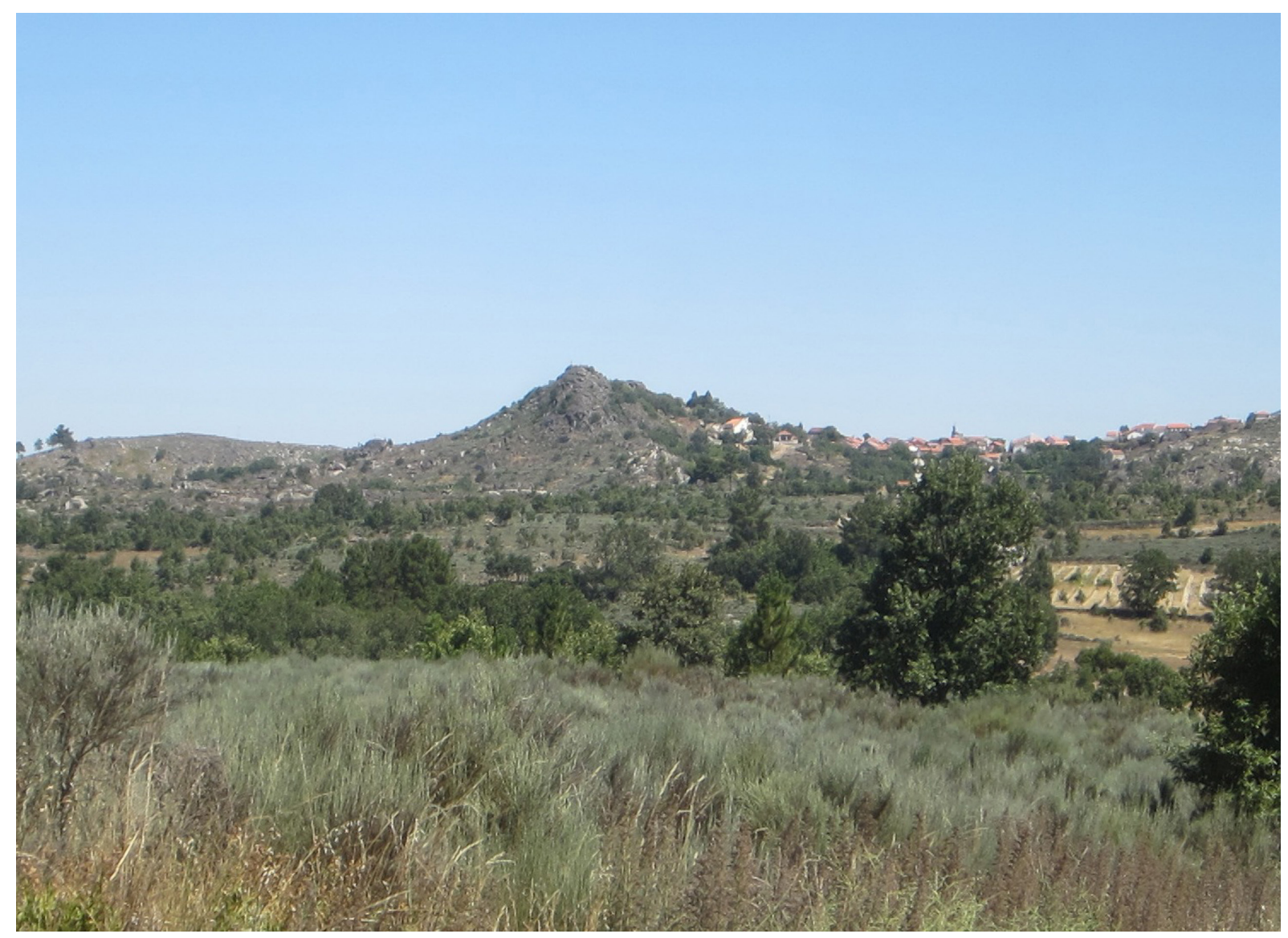

Figura 3. O Alto da Pena, sobranceiro a Vila do Touro.

na última década, ao acompanhamento e intervenção arqueológica com a realização de diversas sondagens (Marques et al. 2011-2012). Tais trabalhos permitiram confirmar o que as prospecções já haviam denunciado, i.e., pelo menos, duas fases de ocupação, uma centrada em inícios do I milénio a.C., portanto finais da Idade do Bronze, outra na II Idade do Ferro, eventualmente sécs. IV/III-II a.C., fase esta bastante mal conhecida na região mas à qual se podem associar algumas produções cerâmicas a torno de grandes recipientes com paralelos em castros extremeños, como La Coraja ou Villasviejas del Tamuja, por exemplo (Fernandes 2016).

O único fragmento cerâmico de tipo Carambolo foi recolhido fora de contexto, em prospecções, pela equipa do Museu Arqueológico do Fundão liderada por João Mendes Rosa, figurando no respectivo catálogo (Vilaça 2007b: 40-41). Este fragmento articula-se com os materiais que permitiram definir aquela primeira fase de ocupação, onde se destaca, além das cerâmicas (Fernandes 2016), um interessante conjunto de artefactos relacionados com a produção do bronze, como moldes, cadinhos, escórias e artefactos de bronze, sendo de sublinhar neste caso uma fíbula de "arco multicurvilíneo" ou de "tipo Ponte 1a", decorada com finas incisões (Vilaça et al. 2011: 442, fig. 5-7), modelo directo da que se encontra figurada em estela do Bronze Final encontrada perto, no Telhado (Fundão), em curso de estudo (Vilaça et al. 2016).

\subsection{Vila do Touro}

Os achados mais recentes de cerâmicas de tipo Carambolo ocorreram em Vila do Touro (fig. 1-1). Este sítio localiza-se a norte dos restantes, na bacia do Alto Côa, no topo de uma elevação de marcada referência espacial, a $830 \mathrm{~m}$ de altitude (fig. 3). Os horizontes visuais são amplos e num ângulo de $360^{\circ}$, alcançando muitas dezenas de quilómetros em redor. Este aspecto terá também motivado a construção de um castelo (todavia inacabado) no século XIII. 
De momento, as intervenções efectuadas permitem-nos dizer que a ocupação proto-histórica parece ter obedecido a um modelo descontínuo de pequenos núcleos condicionados pela topografia acidentada do relevo, que define plataformas propícias à ocupação humana e em parte moldadas pelas práticas agrícolas seculares. As cerâmicas de tipo Carambolo foram encontradas em dois dos sectores intervencionados.

Na plataforma de topo (sector II), numa área de ocupação circunscrita a cerca de $10 \mathrm{~m}^{2}$ e delimitada por afloramentos graníticos pouco proeminentes, identificaram-se três buracos de poste em redor de uma estrutura pétrea subcircular, com c. 80 × $50 \mathrm{~cm}$, correlacionada com a armazenagem de cereais e leguminosas. Associados a esta estrutura registaram-se diversos materiais cerâmicos, líticos e metálicos (um agrafo de cinturão, possivelmente de "tipo tartéssico", dois fragmentos de varetas e um escopro), incluindo também os de tipo Carambolo.

Para este contexto existem duas datas de ${ }^{14} \mathrm{Car}$ bono. A data Sac-3033 foi obtida a partir de madeira carbonizada (Quercus caducifólia) e teve como resultado $2710 \pm 35$ BP. A data Sac-3034, realizada a partir de grãos de trigo, corresponde a $2680 \pm 45 \mathrm{BP}$. Ambas, estatisticamente semelhantes, apontam para o séc. IX a.C.

Cerâmica de tipo Carambolo foi igualmente recolhido no sector III, situado a uma cota inferior, na vertente meridional do relevo, no qual se registou um nível de ocupação também atribuível a inícios do I milénio a.C. Aqui, recolheram-se igualmente fragmentos de tipo Cogotas I, bem como cerâmicas "a peine", tipos com cronologia distinta, como é bem sabido, que se sucedem entre o Bronze Final e o Ferro Inicial, mas que apareceram associados neste sector nos mesmos níveis. Entre os metais o destaque vai para um fragmento disforme de cobre quase puro, interpretado como lingote, e duas fibulas, incompletas, uma de tipo Alcores (Ponte 8a/I.2) e outra de tipo Bencarrón (Ponte 10b/2) (Ponte et al. 2017), cuja cronologia não tem merecido sintonia total entre os especialistas.

\subsection{Quinta das Rosas}

O ponto mais setentrional do Centro Interior de Portugal onde se registou cerâmica de tipo Carambolo encontra-se já no Alto Mondego, na vertente NW da Serra da Estrela, e corresponde ao povoado da Quinta das Rosas (fig. 1-5).

Neste caso, o sítio, a 709 m de altitude, corresponde a ligeira elevação encaixada entre a Ribeira dos Telhais e a Ribeira da Muxagata, com domínio visual alargado no sentido sul, sendo mais limitada a visibilidade localmente. A escavação revelou ocupações no Neolítico Inicial, Calcolítico Final e Bronze Final (Valera 2008).

Esta última fase foi identificada numa zona de abrigo (sector 4) formada por penedos graníticos e a área (sector 5) em redor, com um solo de ocupação, lareira e fossas. De entre cerâmicas com acabamentos brunidos e "cepillados", decoração pós-cozedura e de ornatos brunidos, além de alguns líticos, conhece-se um fragmento com decoração pintada a vermelho. $\mathrm{O}$ contexto foi datado pelo ${ }^{14} \mathrm{Carbono}$ com a data Sac 1964: 2810 40 BP obtida a partir de carvões recolhidos numa das fossas (Valera 2008: 139).

\section{OS CONJUNTOS CERÂMICOS}

O número de fragmentos de cerâmica de tipo Carambolo varia de caso para caso, mas deve ser sublinhado, desde já, a sua presença sempre episódica, mesmo residual, nos respectivos universos ceramológicos. Todavia, não deve ser omitida a possibilidade da existência de um maior número de fragmentos, não identificados, cuja pintura não se conservou.

\subsection{Moreirinha}

No cômputo geral de 4674 fragmentos cerâmicos das campanhas de 1989, 1990 e 1992, reconheceu-se a existência de vestígios de pintura a vermelho em apenas 4 deles.

É de destacar o que oferecia melhor leitura a nível decorativo. Trata-se de uma taça carenada de fabrico fino, com pintura a vermelho sobre superfície brunida de tom cinza-acastanhado, recolhida na camada 1 (fig. 4-1). Os motivos foram aplicados no bordo e definiriam uma sequência de triângulos preenchidos internamente com outros embutidos, com linhas horizontais e oblíquas, sendo delimitados por faixas de linhas paralelas entre si. A pintura desenvolve-se também no bojo, abaixo da carena, não sendo aí, perfeitamente perceptíveis os motivos (Vilaça 1995: 217, 234, Est. CCXXV-2). Um outro fragmento de bojo, pertencente possivelmente ao mesmo recipiente, apresenta ténues traços paralelos entre si dispostos obliquamente ao bordo.

Um terceiro fragmento (fig. 4-5), circunscrito a um bordo, com diâmetro difícil de estimar, possui arranque de asa ou mamilo. Sobre as superfícies brunidas de tom acastanhado, e em ambas, foi aplicada pintura 
de tom vermelho sangue. Na superfície exterior conservou-se um conjunto de linhas paralelas entre si e dispostas obliquamente àquele $\mathrm{e}$, na interior, desenha-se mancha mais indefinida (Vilaça 1995: 302).

Da camada 2 provém o quarto fragmento cuja decoração está resumida a manchas vermelhas localizadas acima da carena, não sendo possível definir com rigor o motivo original (Vilaça 1995: 220).

Da segunda fase de intervenção (1995 e 1996) recolheram-se mais 6 fragmentos de tipo Carambolo, num total de 2820 fragmentos cerâmicos, a que correspondem, pelo menos, dois recipientes (camadas 02 e 03 ).

Três bordos (além de um bojo) pertencem a uma mesma peça cujos fragmentos se encontravam distribuídos numa área restrita (fig. 4-3). Apresenta perfil com suave ressalto e tem cerca de $11 / 12 \mathrm{~cm}$ de diâmetro. O fabrico é muito fino e as superfícies, de tonalidade cinza escura, são ambas intensamente brunidas. Os motivos, executados com traço muito seguro, encontram-se excepcionalmente bem conservados na parte do bordo, enquanto no bojo apenas se vislumbram ténues manchas. Aqueles formam uma sequência de triângulos internamente preenchidos com linhas oblíquas e delimitados por duas faixas paralelas ao bordo, cada uma com três linhas igualmente paralelas entre si.

O segundo recipiente é uma taça carenada com diâmetro máximo de cerca de $19 \mathrm{~cm}$, estando reduzida a quatro fragmentos (fig. 4-2). É de bom fabrico, destacando-se a presença de partículas de mica que conferem brilho às superfícies. Estas são brunidas, de tonalidade entre o acinzentado e o acastanhado. Neste caso a diferença da cor da superfície corresponde a uma das linhas de fractura, pelo que deverá resultar de uma alteração decorrente de distintas condições pós-deposicionais e não do ambiente de cozedura. A pintura conserva-se apenas num dos fragmentos, encontrando-se bastante sumida, mas é perceptível que seria à base de triângulos preenchidos de forma homogénea numa tonalidade de vermelho sangue. Todavia, o mais interessante desta peça é que a pintura foi aplicada sobre uma superfície ela própria já decorada com ténues motivos brunidos definidos por feixes de linhas formando ziguezague, entre a extremidade do bordo e a linha da carena. Por conseguinte, a pintura parece não ter respeitado integralmente a decoração brunida pré-existente, ou seja, em termos conceptuais e estéticos a decoração parece ter sido reprogramada, sugerindo uma manipulação estilística do recipiente feita a dois tempos.

Restam dois outros bojos (fig. 4-4) pertencentes a recipiente de forma desconhecida mas de tendência globular, de tonalidade castanho-acinzentada. A decoração seria à base de motivos com linhas paralelas entre si, de que se conservaram pequenos troços interrompidos; aparentemente, haveria outros motivos hoje impossíveis de reconstituir.

\subsection{Cachouça}

Contam-se apenas 9 fragmentos com pintura a vermelho num total de 1769 registos efectuados na área Norte, a única onde apareceu esta categoria de cerâmica (Vilaça 2007a). Reportáveis a dois recipientes distintos, alguns admitem colagens, destacando-se, todavia, a sua extrema fracturação.

Um deles (fig. 5-1) corresponde a bordo vertical com ligeira inflexão externa, de lábio biselado, extremamente fino e cujo diâmetro é estimado em cerca de $7 \mathrm{~cm}$. As superfícies são brunidas, de tom castanho-acinzentado e a pintura é definida por traços muito finos paralelos ao lábio, sob os quais foi desenhado motivo mais elaborado, com métopas, alternando possíveis losangos preenchidos com linhas oblíquas com grupos de outras verticais paralelas entre si.

Um outro bordo (fig. 5-2) de lábio mais exvertido possui idêntico fabrico, depurado, com pequeníssimas partículas de mica. Sobre as superfícies brunidas, de tom castanho-acinzentado, foi aplicada pintura de tom vermelho tinto na face exterior. Os motivos correspondem a banda de quatro linhas paralelas junto ao lábio e, abaixo, apresenta-se uma sequência de triângulos preenchidos internamente com linhas oblíquas. A este recipiente pertenceriam os restantes fragmentos da zona do colo/ bojo. Tratar-se-ia de um pequeno pote de colo vertical e corpo de tendência globular, cuja decoração se desenvolvia desde o bordo até, pelo menos, a linha de inflexão da pança. Nesta área repete-se faixa ou banda de quatro linhas paralelas, tal como as que se encontram junto ao lábio, abaixo da qual foi pintada barra definida com quadrados/rectângulos preenchidos com linhas verticais que alternam com outros lisos. Note-se que a pintura, muito fina neste caso, evidencia extrema minúcia no traçado.

\subsection{Cabeço da Argemela}

O único fragmento deste sítio corresponde a um pequeno bordo vertical, ligeiramente estrangulado, formando um colo muito curto que antecede suave carena (fig. 6). O corpo do recipiente seria tendencialmente ovoide. Possui bom fabrico, com superfícies engobadas, 


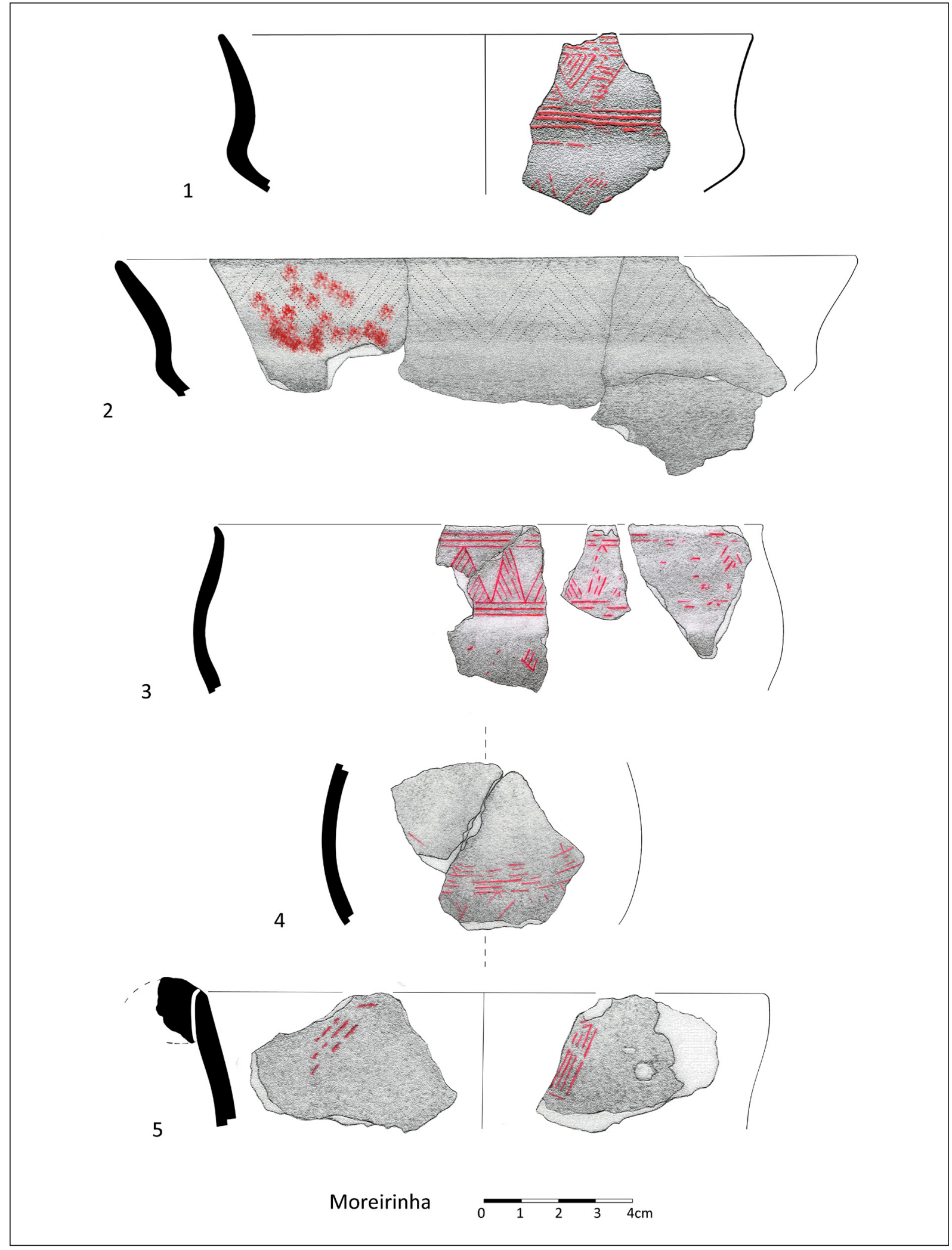

Figura 4. Moreirinha, cerâmicas de tipo Carambolo. 


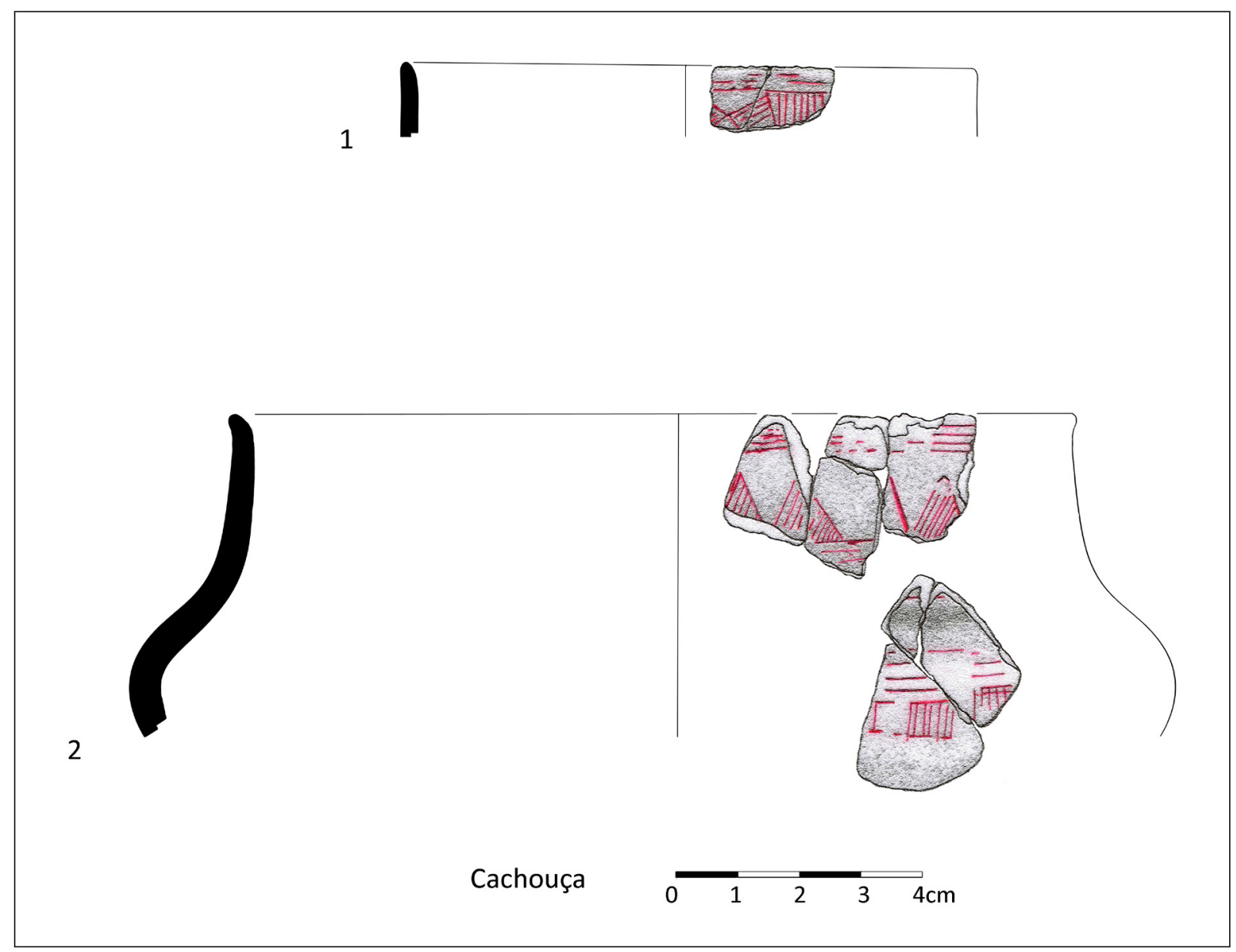

Figura 5. Cachouça, cerâmicas de tipo Carambolo.

de tom castanho claro. A decoração, em tom vermelho tinto, está presente em ambas as superfícies. A exterior é definida por uma banda de quatro linhas paralelas junto ao lábio separadas por uma área em reserva na zona do estrangulamento de um outro grupo definida por três linhas. Imediatamente abaixo destas desenvolve-se uma sequência de losangos unidos e internamente preenchidos com linhas oblíquas entre si. O traço é fino e muito regular. $\mathrm{Na}$ superfície interior a pintura, na mesma tonalidade, circunscreve-se à extremidade superior do bordo, junto ao lábio, replicando o motivo de linhas pintadas da superfície exterior.

\subsection{Vila do Touro}

Do sector II de Vila do Touro são provenientes 4 dos 9 fragmentos de tipo Carambolo recolhidos nesta estação. Mantem-se o carácter absolutamente residual destas cerâmicas no cômputo geral, uma vez que este totaliza, neste sector, 599 fragmentos.

Um dos fragmentos corresponde a pequeno bojo com ligeira inflexão superior exvertida, embora insuficiente para definir a forma (fig. 7-1). As tonalidades do engobe e da pintura são, respectivamente, castanho-claro e vermelho tinto. A existência de decoração neste bojo confirma, de novo, a abrangência da área decorada neste tipo de cerâmicas, sendo aqui definida por uma faixa de quatro linhas paralelas horizontais, acima e abaixo das quais haveria outras composições, impossíveis de reconstituir, talvez triângulos ou losangos. As linhas pintadas são de espessura variável, atingindo as mais largas quase $1 \mathrm{~mm}$, só comparáveis às de um outro recipiente da Moreirinha.

Um segundo fragmento é um bordo de lábio biselado, de fabrico muito depurado e muito bem cozido (fig. 7-2). Estima-se um diâmetro à volta dos $6 \mathrm{~cm}$. A pasta é acinzentada e as superfícies são engobadas 
Figura 6. Cabeço da

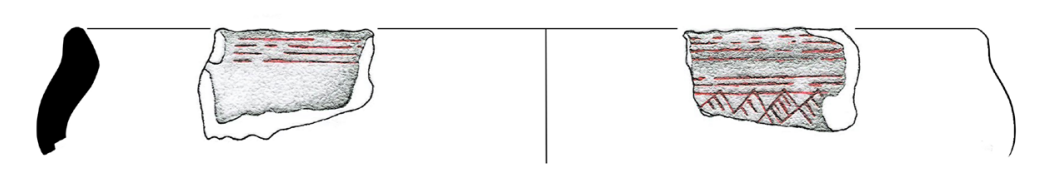

Argemela

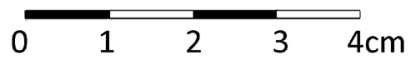

Argemela, cerâmica de tipo Carambolo.

(a interior com vestígios de espatulamento) apresentando cor castanho-clara, cor que contrasta com o vermelho 'bordeaux' da pintura. Os motivos apresentam-se bastante sumidos, embora seja perceptível, a existência de duas faixas de linhas paralelas ao bordo que delimitam espaço onde parecem ter existido motivos com linhas orientadas obliquamente àquelas, certamente triângulos ou losangos.

Os outros dois fragmentos, ambos bojos, poderão corresponder a um mesmo recipiente (fig. 7-4 e 7-7). Quer os fabricos e pastas, quer a forma, destoam dos restantes exemplares até agora analisados. Estas, embora bem cozidas e finas, apresentam tratamento final menos cuidado, sobretudo nas superfícies interiores, que chegam a ser bastante irregulares. A tonalidade é idêntica em ambas as superfícies. Externamente encontram-se também alteradas por desgaste ou fracturas várias. $\mathrm{O}(\mathrm{s})$ recipiente(s) a que correspondiam $\operatorname{seria}(\mathrm{m})$ provido(s) de um colo e o corpo apresenta forma tendencialmente bicónica. A pintura, de traço fino, talvez aplicada com matriz de tipo pente, é de tom vermelho escuro. Os motivos possíveis de reconstituir estão representados, num dos fragmentos, por feixes de várias linhas horizontais abaixo das quais se desenharam outros de linhas orientadas vertical e obliquamente em relação àquelas (fig. 7-7). No outro fragmento haveria um conjunto de, pelo menos, três linhas horizontais, desenvolvendo-se na zona inferior, onde o perfil é mais saliente, uma sequência de motivos repetitivos, talvez triângulos com traços internos oblíquos (fig. 7-4).

Do Sector III provêm 5 fragmentos. Um deles é um bordo de lábio biselado exvertido, com cerca de $8 \mathrm{~cm}$ de diâmetro (fig. 7-3). O fabrico é fino e as superfícies são bastante brunidas, acastanhada no exterior e cinzenta escura na interior. A decoração, em tom vermelho escuro foi aplicada no exterior e nela sobressai um conjunto sequencial de triângulos rectângulos (diferentes de todos os outros já comentados) bastante esguios, os quais seriam delimitados por duas faixas de linhas horizontais. O traçado é de finura extrema e deverá ter sido executado com matriz pontiaguda. Importa ainda observar que em certas áreas desprovidas de pintura, desaparecida, parece existirem ténues traços brunidos.

Os restantes 4 são bojos. Um deles, ligeiramente arqueado, é de excelente qualidade a nível de fabrico e acabamento, possuindo pasta depurada e superfície exterior muito brunida, com brilho quase metálico (fig. 7-6). Tem cor cinzenta escura, pelo que a pintura, reduzida a pequenas manchas esparsas de vermelho vivo é bem evidente, embora indefinida. Todavia, não se vislumbram sinais de decoração linear. Estas observações aplicam-se a um outro pequeno bojo, não desenhado.

Sobre o terceiro e o quarto fragmentos pouco mais se pode dizer (fig. 7-5). A pasta é mais grosseira, as superfícies são brunidas e a sua cor, tal como a da pintura, são idênticas às dos fragmentos anteriores. Os motivos reduzem-se a manchas difusas. Mas neste caso, e isso distingue-os, a pintura foi aplicada na superfície interior.

\subsection{Quinta das Rosas}

Encontra-se publicado um único fragmento cerâmico, um bordo, decorado com ornatos brunidos e com pintura a vermelho sobre traços brunidos, embora se refira a existência de 12 fragmentos (Valera 2008: 139 e fig. 3). Trata-se também do único caso abordado neste trabalho que não pudemos observar directamente.

Os motivos correspondem a triângulos alongados sequenciais delimitados por bandas de linhas paralelas (fig. 8). Este fragmento é ainda muito interessante porque conjuga decoração brunida e pintada (Valera 2008: 139), assunto que discutiremos adiante. 


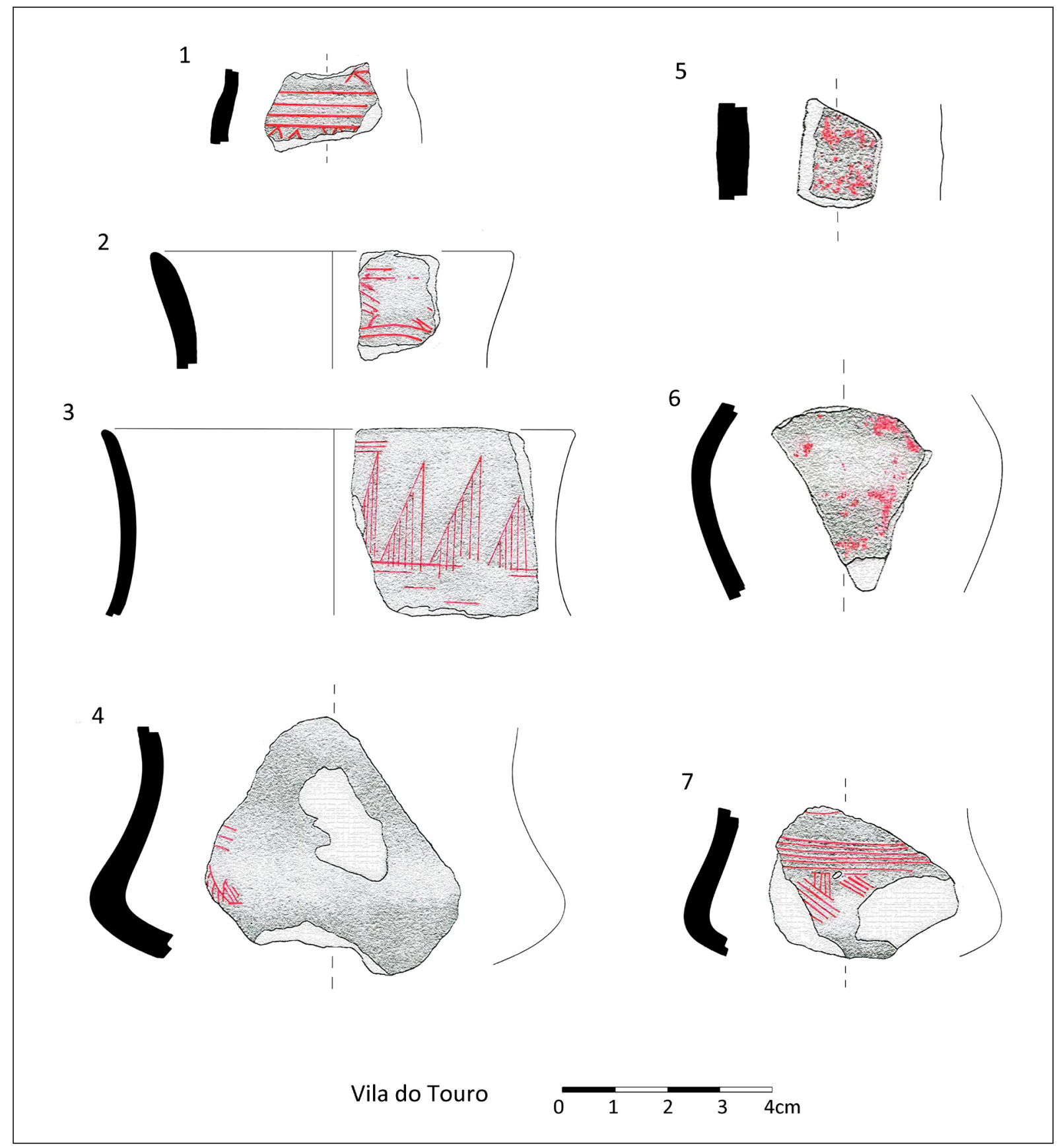

Figura 7. Vila do Touro, cerâmicas de tipo Carambolo.

\section{VISÃO INTEGRDA DA AMOSTRA}

\subsection{Formas, fabricos e decoração}

A análise das cerâmicas de tipo Carambolo do Centro Interior do território português, totalizando 40 fragmentos correspondentes a um número mínimo de 12 recipientes, todos de fabrico manual, não permite classificá-las como um conjunto homogéneo, verificando-se alguma diversidade ao nível das formas, dos fabricos e da decoração. Essa diversidade reside não só entre os vários conjuntos, mas também no interior de cada um, muito em especial nos casos da Moreirinha e de Vila do Touro, onde o número de exemplares é superior. 
Os 10 fragmentos da Moreirinha, que corresponderão a um mínimo de quatro recipientes, possuem formas e fabricos idênticos aos das produções regionais de cerâmicas finas, com destaque para as taças carenadas de tipo 1 da Moreirinha, Alegrios, Monte do Frade e Castelejo (Vilaça 1995: 271). Apresentam superfícies de tonalidades escuras, entre o castanho-acinzentado e o cinzento escuro; num caso a pintura foi aplicada em ambas as superfícies.

Registaram-se duas tonalidades de vermelho, uma mais aberta, de vermelho vivo, outra um pouco mais carregada, de tom vermelho tinto. Esta situação parece traduzir a existência de duas opções na variante cromática na 'paleta do(a) pintor(a)', entendido(a) este(a) num sentido abstracto e genérico, uma vez que não há qualquer base credível, nem provável, para defender uma única autoria de todo o conjunto cerâmico pintado.

Pelo contrário, e embora também sem qualquer suporte que o permita confirmar, poderá ter havido duas mãos ou "tendências", uma que valorizou a aplicação de motivos lineares geométricos, outra que optou pela coloração a cheio de motivos triangulares (fig. 4-2, 9 e 10). Neste caso, e ao contrário dos demais, verificou-se que a pintura não foi aplicada directamente sobre a superfície brunida, mas sobrepõe-se a ténue e prévia decoração brunida, sugerindo duplicidade a nível técnico e decorativo, aspecto de manifesto interesse, situação que se repete também no fragmento da Quinta das Rosas (fig. 10) e, eventualmente, num outro de Vila do Touro. Quanto aos motivos lineares, é de sublinhar a sua assinalável regularidade, talvez só conseguida se executados com matriz de tipo pente, sendo também dos mais largos de todo o conjunto (cerca de $1 \mathrm{~mm}$ ). $\mathrm{O}$ efeito estético daí resultante é visualmente muito forte pelo contraste da pintura vermelha sobre o fundo cinzento escuro de um dos recipientes (fig. 4-3 e 11).

Os 9 fragmentos registados na Cachouça correspondem a um número mínimo de dois recipientes. Tal como na Moreirinha, formas e fabricos são idênticos aos das produções das cerâmicas finas manuais do local. Aqui estão ausentes taças carenadas pintadas, mas foi identificado um pequeno pote com paralelos nos tipos 2A do Castelejo e Moreirinha (Vilaça 1995: 96, 117, 232) e $10 \mathrm{~A}$ do Monte do Frade, tipo que pode ocorrer em formas lisas ou com decoração de sulcos brunidos (Vilaça 1995: 132, 155).

$\mathrm{O}$ tom da pintura destes fragmentos não é rigorosamente o mesmo, embora correspondam a tonalidades de vermelho tinto. Num dos recipientes (fig. 5-2) os motivos repetem a composição decorativa à base de faixas de linhas paralelas e triângulos sequenciais preenchidos

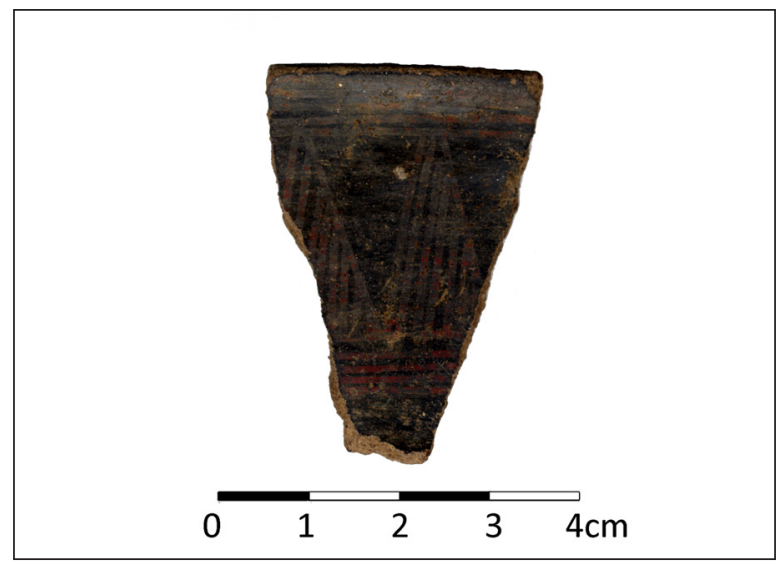

Figura 8. Quinta das Rosas, cerâmica de tipo Carambolo (foto de A.C. Valera).

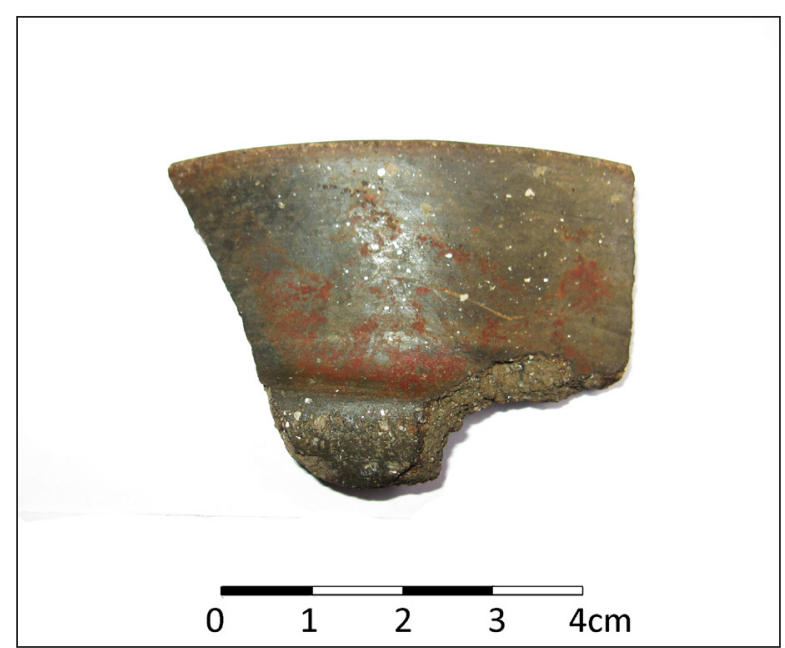

Figura 9. Fragmento 2 da Moreirinha, observando-se manchas dispersas de pintura.

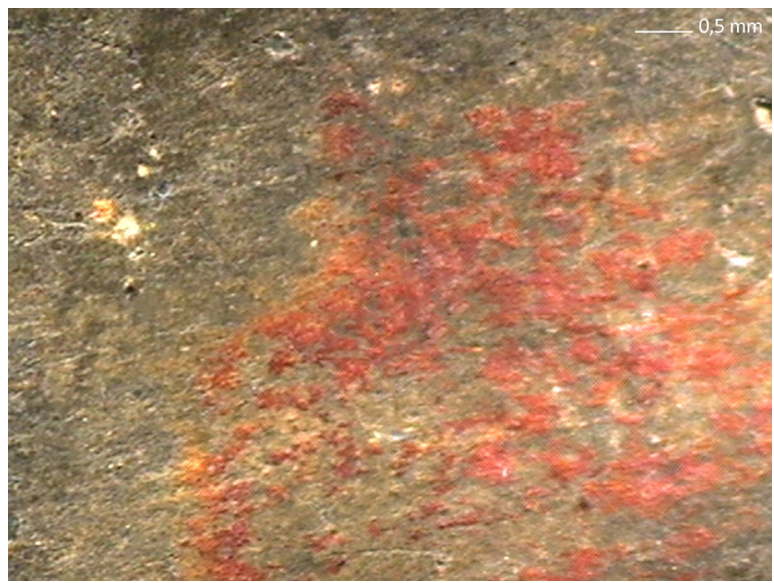

Figura 10. Pormenor da pigmentação do fragmento 2 da Moreirinha, observando-se manchas dispersas (foto por XRF). 


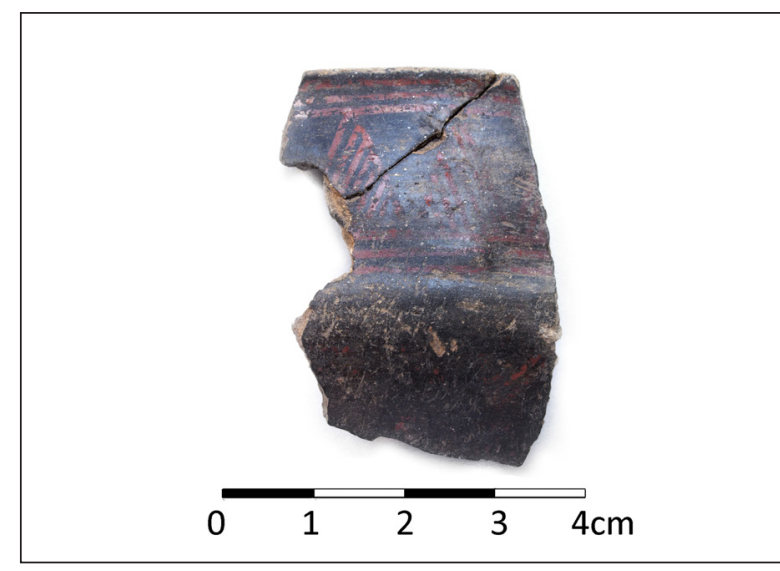

Figura 11. Fragmento 3 da Moreirinha, evidenciando-se o forte contraste entre a pintura vermelha e o fundo cinzento escuro (foto de A. Pernas).

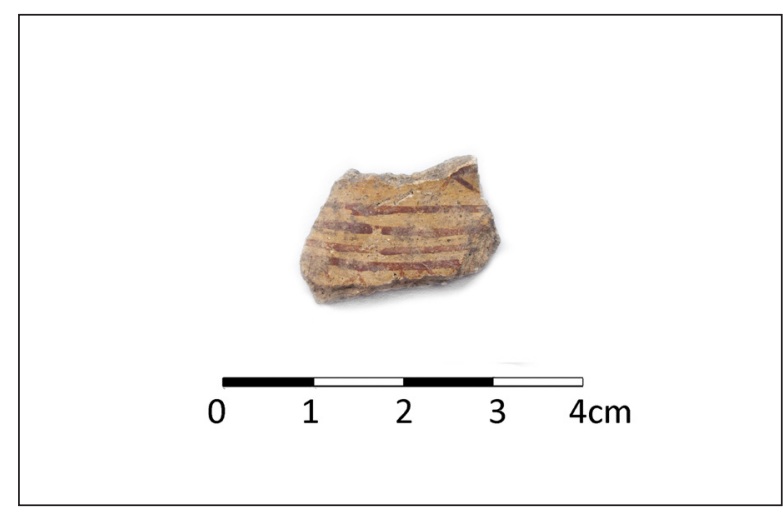

Figura 12. Fragmento 1 de Vila do Touro, observando-se o traçado irregular da decoração (foto de A. Pernas).

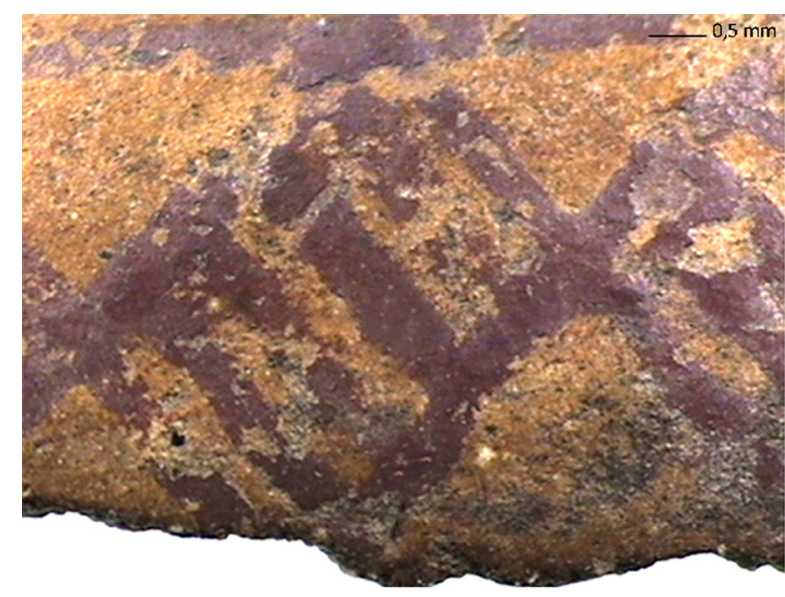

Figura 13. Pormenor do fragmento da Argemela (amostra A) mostrando o pigmento vermelho com traços bem definidos sobreposto ao engobe. com linhas oblíquas que se encontra na Moreirinha (fig. 4-3). Todavia, e ao contrário do que foi observado nos exemplares desta última estação, a decoração nos fragmentos da Cachouça apresenta o traçado a espaços mais irregulares, sugerindo uma aplicação feita com instrumento de ponta única e muito mais fina (cerca de $5 \mathrm{~mm}$ ), pincel, ou instrumento muito aguçado (metálico, de osso, de madeira ?). A Cachouça destaca-se ainda, em relação a todos os outros casos, por oferecer composições mais elaboradas, concretamente metopadas, as quais tanto ocorrem no bordo, com linhas verticais e losangos (fig. 5-1), como no bojo (fig. 5-2). Por deficiência de conservação e pela diminuta dimensão dos fragmentos, não é possível compreender a sequência na totalidade.

Pelo contrário, e não obstante tratar-se de um pequeníssimo bordo, o único registo com motivos em losango dispostos de forma aditiva foi encontrado no Cabeço da Argemela (fig. 6). É também revelador da variedade de soluções adoptadas em termos decorativos numa mesma região. Já o contraste resultante da decoração a vermelho de tom 'bordeaux' sobre o tom castanho claro do engobe, só encontra situação similar entre os fragmentos de Vila do Touro.

O conjunto das cerâmicas de Vila do Touro é o mais heterogéneo, a nível dos fabricos, acabamentos e formas, apesar de tratar-se de um pequeno grupo de 9 fragmentos a que corresponderão, no mínimo, quatro recipientes. Infelizmente, pouco se pode dizer sobre as formas, mas devem ser sublinhados os perfis de tendência bicónica, ou com carenas baixas, que se aproximam, em certa medida, de determinados exemplares lisos do Castelejo e Moreirinha (Vilaça 1995: 117, 232, 271).

A heterogeneidade do conjunto manifesta-se igualmente nas pastas, em dois casos de assinalável dureza e compactidade, justamente os que levam engobe de tom castanho-amarelado (fig. 7-1, 7-2 e 12), fragmentos que destoam dos fabricos conhecidos da Beira Interior, incluindo o do fragmento do Cabeço da Argemela, com o qual são maiores, ainda assim, as similitudes.

Tal como verificado neste último sítio e na Moreirinha, a aplicação de pintura entre os fragmentos de Vila do Touro pode verificar-se em ambas as superfícies. São diversas as tonalidades da pintura, percorrendo matizes desde o vermelho tinto ao vermelho sangue, de tendência alaranjada (fig. 7-5, 7-6), neste caso a tonalidade mais clara de todos os fragmentos observados neste estudo.

Embora bastante incerto, admitimos que num dos exemplares (fig. 7-3) poderá ter sido aplicada pintura sobre ténues traços de decoração brunida, mas esta 
Quadro 1. Formas dos recipientes com decoração tipo Carambolo na Beira Interior.

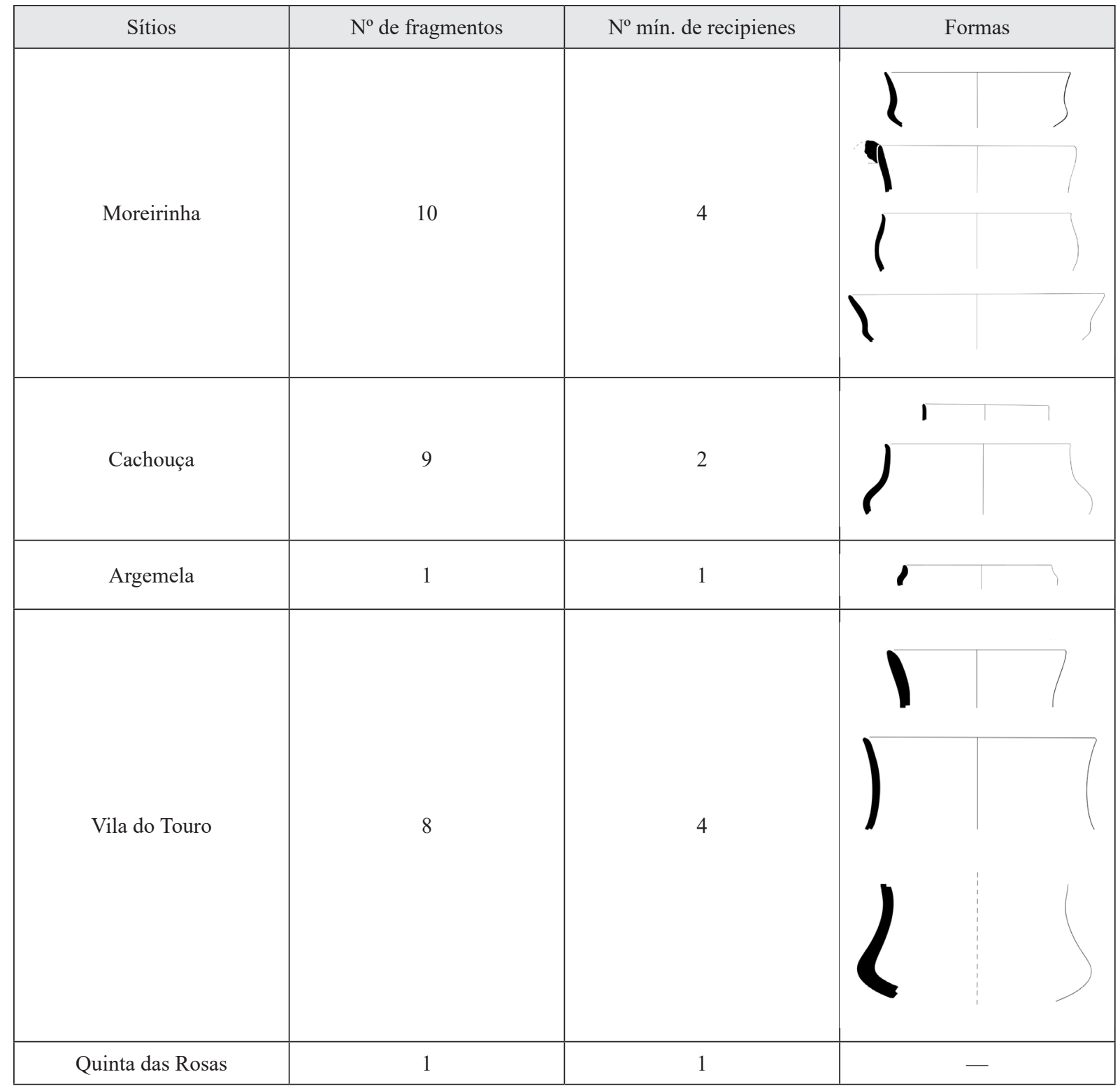

situação não é comparável à que observámos num dos exemplares da Moreirinha, bastante explícita. Enquanto nesta foram executados motivos decorativos distintos, entre o brunido e a pintura, em Vila do Touro pintura e eventuais sulcos brunidos coincidem em absoluto.

Quanto às formas (quadro 1), destacam-se as taças carenadas, bem conhecidas regionalmente, e as formas de colo curto e corpo globular, ou de perfil tendencialmente bicónico, formas estas bastante mais expressivas no Baixo Guadalquivir (v.g. tipo A.I.f, fase pré-fenícia)
(Ruiz Mata 1995: 268, fig. 293), pautando-se todos os exemplares pela sua pequena capacidade volumétrica. Por contraste com alguns exemplares da região andaluza, nomeadamente de El Carambolo, onde se encontram também recipientes de maior dimensão (além dos característicos 'suportes de carrete', também desconhecidos aqui), as cerâmicas de tipo Carambolo na Beira Interior apenas poderiam ter servido para conter substâncias, sólidas ou líquidas, em quantidade ínfima e, nessa medida, também certamente raras e de elevado valor. 
Neste aspecto concreto, a Beira Interior acompanha a Alta Extremadura, onde faltam igualmente os vasos de grande dimensão, circunscrevendo-se os exemplares pintados a formas carenadas e bicónicas, como sucede, por exemplo, em Valcorchero e Boquique (Almagro Gorbea 1977: 86, 96, 125).

Os fabricos são sempre finos, com pastas depuradas, em certos casos de elevada qualidade, com acabamentos muito polidos, brunidos, ou com engobe, à semelhança da mestria de outras produções regionais de finais da Idade do Bronze. Todavia, não é tudo a mesma coisa, sendo manifesta a manipulação de tipos de argilas distintas, pelo que será necessário proceder, no futuro, à análise de pastas deste universo cerâmico. Desejavelmente, essa análise deverá comportar, além desta amostragem, outros exemplares, seja do interessante núcleo alentejano, seja de contextos do Baixo Guadalquivir. Neste caso, ao que cremos, apenas se encontra disponível a análise mineralógica de um fragmento de tipo Carambolo do Cabezo de San Pedro (Huelva), onde se identificou tremolita, elemento que o distingue das restantes cerâmicas analisadas, de acordo com V. Galván (Ruiz Mata e Fernández Jurado 1986: 297). Por conseguinte, é fundamental um estudo comparativo, que possa proporcionar algumas pistas minimamente seguras sobre a identificação de produções locais ou alógenas e, consequentemente, sobre a escala de circulação das cerâmicas de tipo Carambolo, genuínas ou imitadas, nestas regiões interiores e mais ocidentais, contando também com a Extremadura e Meseta sul. A este propósito, sublinhe-se a importância das análises mineralógicas efectuadas a distintos tipos cerâmicos, incluindo Carambolo, de Alarcos (Ciudad Real), com a identificação de olivino, mineral próprio das áreas vulcânicas, que permitiu formular a hipótese de uma produção regional (García Huerta e Morales Hervás 2017: 120-121).

Em suma, os testemunhos estudados encontram ao nível das formas, fabricos e decoração em geral vários paralelos entre outras cerâmicas da Beira Interior e da Extremadura, sobretudo a Alta Extremadura, com a qual partilha idênticas afinidades culturais.

\subsection{A geometria da cor}

A especificidade decorativa desta categoria de cerâmicas exige uma abordagem que pretendemos agora mais focalizada, numa análise a dois tempos, ainda que não dissociados, a nível estritamente técnico e a nível decorativo.

\subsubsection{Os gestos do (a) pintor(a)}

De um ponto de vista técnico, a aplicação de pintura, a vermelho, constitui absoluta novidade na Beira Interior, revelando assinalável mestria.

A pintura é monocromática mas percorre distintas intensidades entre o vermelho sangue (fig. 10), por vezes quase laranja, e o vermelho tinto (fig. 13), tonalidades essas que nunca se encontram associadas num mesmo exemplar. Todavia, constituem excepção as situações em que as linhas pintadas se sobrepõem ou se cruzam (duas e três vezes), dando origem, nesses pontos, a uma tonalidade mais carregada resultando da acumulação de camadas de tinta (fig. 14). A tonalidade vermelha contrasta sempre com as superfícies, mais claras ou mais escuras, daí acabando por resultar sempre, em termos visuais, acentuado bicromatismo. Se a Moreirinha e a Cachouça privilegiaram os tons mais escuros das superfícies, entre acinzentados e acastanhados, a Argemela e Vila do Touro foram também receptivos às tonalidades mais claras, de beges-alaranjados.

A aderência da pintura, que pode ocorrer em ambas as superfícies, só nos bordos ou nestes e até cerca de $2 / 3$ do recipiente, manifesta-se de forma distinta. Sem subestimar os efeitos provocados por condições pós-deposicionais, nomeadamente pela acção dos agentes químicos dos solos, neste caso de pintura pós-cozedura com particular vulnerabilidade, como há muito tempo se chamou a atenção (Blasco Bosqued 1980-1981: 75), parece-nos que as realidades observadas resultarão mais de outros factores e não tanto estritamente de condições de deposição. Estas são óbvias, porém, na alteração da cor das superfícies das cerâmicas e na deficiente conservação da pintura que, em maior ou menor grau se verificou, e que, no exemplar da fig. 4-2, é bem elucidativo.

Terão de ser equacionadas outras razões para a distinta tonalidade da pintura e respectiva conservação. Certamente que o uso de diferentes substâncias corantes (tipos de óxidos de ferro, cf. infra) e de diferentes solventes ou fixadores utilizados na emulsão (água, urina, resinas, gordura animal, sangue, etc.?) serão determinantes nesse campo. A consistência da tinta, mais ou menos diluída, o seu maior ou menor grau de secura no momento da aplicação, terão sido condicionantes responsáveis pelos resultados obtidos. Por exemplo, na amostra destaca-se o exemplar do Cabeço da Argemela (fig. 13) em que é notório um indelével relevo na parte pintada, sugerindo isso mesmo, uma emulsão mais espessa, ou, em alternativa, menos provável, a pintura do traçado repetida várias vezes. 
Mas não menos pertinentes serão a própria técnica de aplicação da tinta, a natureza da superfície de suporte (alisada, brunida, engobada, ou sobre motivos brunidos), ou ainda o momento em que a pintura é efectuada no âmbito da cadeia operatória da concepção do recipiente. Efectivamente, se a aplicação da pintura é pós-cozedura, não é nada certo que a pintura seja, sempre, o último gesto do artífice, quer dizer, em alguns casos poderá ter ocorrido um brunimento final de toda a superfície da peça numa fase pós-pintura, como bem observaram Buero Martínez e Fernández Gómez (2010: 53), tal como um quadro pintado a óleo leva uma última camada de verniz protector. Na amostra que estudámos temos situações em que a pintura é bastante brilhante (fig. 11), indicando tratamento brunido ou polido a posteriori, e outros em que ela é mate (fig. 15), sugerindo ter sido aí a pintura a etapa final do processo.

Na verdade, a(s) técnica(s) de aplicação da pintura é assunto ainda pouco explorado na bibliografia, não obstante os valiosos contributos daquele último trabalho, onde os autores também defendem o uso do torno lento ou torneta na finalização das peças, inclusive na ajuda da aplicação da pintura com pincel.

As observações permitiram-nos distinguir realidades diversas. Desde logo, é fundamental sublinhar que o conjunto cerâmico estudado, muito embora a designação de cerâmica de tipo Carambolo com que o identificámos, engloba, além da peculiar decoração linear/ geométrica a vermelho, também a aplicação compacta e homogénea de pintura, que se traduz nas manchas esparsas conservadas (fig. 4-2; 7-5, 7-6, 9 e 10). Nesta situação particular a aplicação da pintura terá sido concretizada com pincel ou com outro mediador afim, nomeadamente utilizando os próprios dedos da mão.

Mas nos casos em que a pintura originou motivos lineares é necessário admitir, evidentemente, outras soluções, até porque também eles comportam distintas situações. A regularidade, firmeza e fineza de alguns dos traços (cerca de 0,5 mm) (fig. 11 e 15), impressionante, talvez só tenham sido conseguidas através da aplicação da tinta com matriz de tipo pente, com pincéis múltiplos, ou recorrendo à estratégia supra-mencionada do uso da torneta. Pelo contrário, em outras evidências a decoração exibe traçado mais grosseiro (fig. 12) e, sobretudo, de maior irregularidade no traço e entre traços, denunciando outras mãos, ou pincéis, que actuaram de forma mais livre.

Como poderemos imaginar esses pincéis de diminuto calibre? Um feixe de cabelo ou de pelo de cabra, ou antes, tão-só, uma cerda rija de javali? A experiência que realizámos recorrendo a pelo de cabra (da Serra

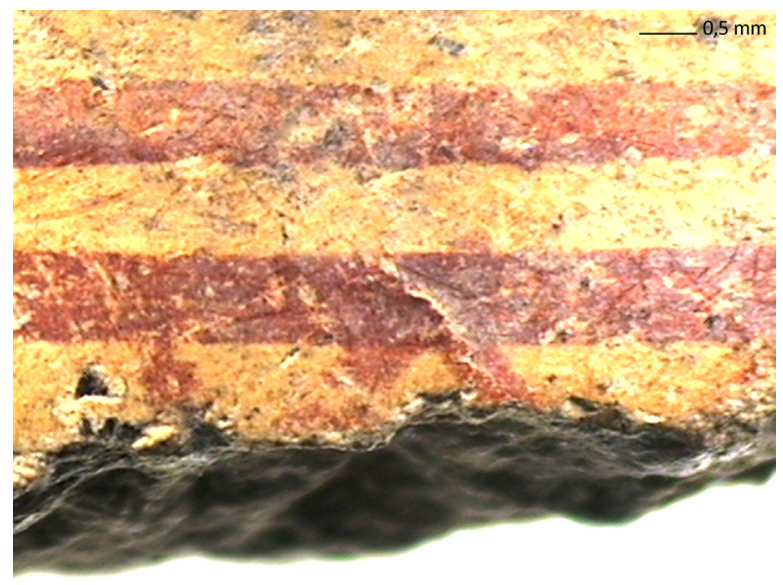

Figura 14. Fragmento 1 de Vila do Touro observando-se diferente tonalidade da pigmentação quando se verifica sobreposição dos motivos.

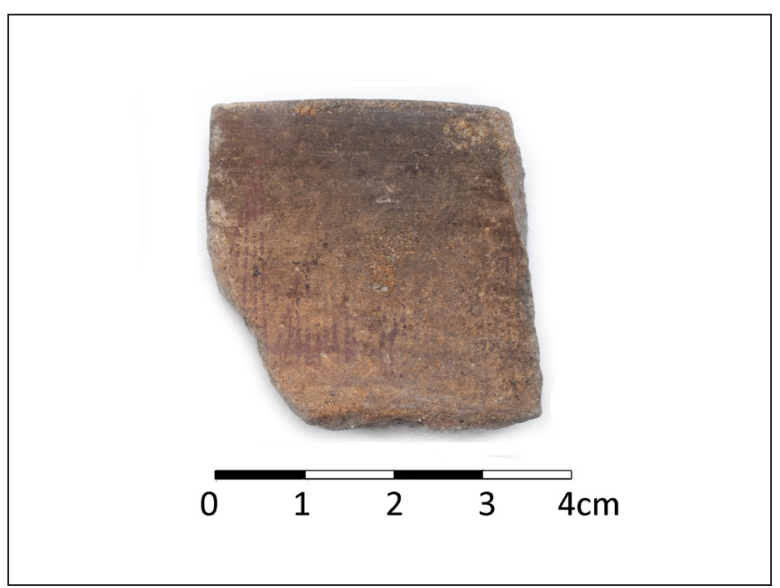

Figura 15. Fragmento 3 de Vila do Touro, com decoração a traço muito fino (foto de A. Pernas).

da Malcata) com o qual preparámos um fino pincel utilizado na pintura (com sangue) de fragmento cerâmico arqueológico, revelou a admissibilidade dessa hipótese. Ou também terão sido utilizados instrumentos rombos para aplicação da tinta? Também neste campo a arqueologia experimental poderá ter uma palavra esclarecedora, com tão bom proveito quanto os resultados obtidos em interessante estudo desenvolvido por Papadopoulos et al. (1998). Visando o entendimento da pintura de círculos e semicírculos concêntricos em variados recipientes cerâmicos do Egeu e Mediterrâneo, nomeadamente do período Protogeométrico, os autores levaram a cabo diversas experiências, socorreram-se da criação de uma matriz múltipla, composta por uma haste de madeira vertical, conectada ao centro a 
uma barra horizontal, mais curta, e na qual encaixaram vários pincéis, compostos de cabelo humano ou de pelo de cabra, e que permitiram a réplica de vários padrões, como faixas, faixas onduladas e ziguezagues (Papadopoulos et al. 1998: 508-509, fig.1). Note-se que, etnograficamente, ficou comprovada a utilização de uma matriz muito semelhante por oleiros libaneses.

Um dos aspectos mais interessantes do estudo efectuado foi a confirmação de que a decoração pintada de tipo Carambolo pode sobrepor-se, por vezes, a prévia decoração de ornatos brunidos: exemplares da Quinta das Rosas e Moreirinha (fig. 8 e 9) inscrevem-se nesta problemática. Sublinhe-se que não se trata propriamente da associação de duas técnicas decorativas, uma vez que a pintura ocultou os ornatos brunidos, quer dizer, anulou os efeitos estéticos pré-existentes, mesmo quando os repete, conferindo-lhes, assim, visibilidade, mas de um outro modo. De facto, também neste domínio parece ser possível detectar duas situações distintas.

Uma, em que a pintura coincide com a decoração brunida (fig. 7-3); outra, em que a sobreposição difere, tratando-se manifestamente neste caso de dois "programas" distintos (fig. 4-2 e 9). Se assim foi, é admissível pensar que a biografia dessas cerâmicas não foi regular, quer dizer, num determinado momento sofreram uma transformação decorrente da pintura adicionada.

Todavia, o problema não é simples e sobre ele já reflectiu Ana Osório (2013: 140-141). Sugere esta investigadora que nos casos em que se verifica coincidência entre motivos brunidos e pintados, estes poderão ter resultado da aplicação da pintura com instrumento rombo, ou seja, a decoração era apenas pintada, sendo o brunido simplesmente um efeito secundário e, obviamente, involuntário. É hipótese a não descurar.

É também admitido que a decoração brunida poderia corresponder a marcação prévia do desenho para o pintar melhor, sugestão esta que nos parece menos plausível. Os custos adicionais, nomeadamente de tempo, decorrentes do investimento inerente à concretização de decoração brunida talvez não o justificassem, pelo que consideramos esta hipótese menos provável.

Como terceira possibilidade, considera ainda que terá mesmo havido a intenção de "recriar" a decoração pintada sobre uma decoração brunida pré-existente, ideia que merece ser considerada. Neste sentido, essa acção poderia decorrer do objectivo específico de dar maior visibilidade aos ornatos brunidos - na realidade mutáveis em função da luz e da perspectiva em que se coloca o observador -, avivando-os, refigurando-os, mesmo ocultando-os, porque pintando-os, ou seja, diferem as técnicas, mantêm-se os motivos, reforçados. Em alternativa, e de forma menos prosaica atendendo à categoria de excepção destas cerâmicas, a pintura poderia expressar um processo mimético e de emulação consubstanciado nos mesmos suportes, nas mesmas entidades, mantendo-se a simbologia inerente e pré-existente.

Eis, sem dúvida, uma problemática a explorar e que deixa em aberto a probabilidade de algumas dessas cerâmicas terem passado em algum momento das suas "vivências" por um processo subtil metamorfoseado, mantendo-se o imutável - a forma -, mas alterando-se a aparência e a estética - decorrente da pintura adicionada.

\subsubsection{Motivos e composições}

Como ficou já bem explícito, os motivos e composições que foi possível inferir a partir dos fragmentos, que sintetizamos no quadro 2, são todos de cariz linear e geométrico. Correspondem a composições pouco elaboradas e, nessa medida, também muito distantes do complexo universo conceptual e estético de matriz orientalizante de determinadas cerâmicas de tipo Carambolo do Baixo Guadalquivir, onde, além desses mesmos motivos, também o figurativo, com zoomorfos (aves, caprídeos), fitomorfos e esteliformes e as bandas com métopas assumem especial significância, inclusive religiosa, que se admite relacionada com o culto a Tanit/ Astarté (Buero Martínez 1984: 363; Casado Ariza 2015: 221; 244). Nada disso, que chega a comportar por vezes um certo barroquismo, com composições complexas e invasoras, se encontra nestas regiões mais setentrionais, absolutamente dominadas pela gramática decorativa de cariz geométrico que encontramos em muitas outras categorias cerâmicas regionais. Neste ângulo de análise específico, poderemos dizer que as cerâmicas de tipo Carambolo espelham dois mundos distintos, inclusive a nível cronológico.

As cerâmicas da Beira Interior sistematizam-se nos seguintes elementos básicos, comportando variáveis (quadro 2): linhas paralelas (1), triângulos de tipo diverso (2), losangos (3), rectângulos (4) e escalariformes (5). Estes elementos conjugam-se e dão origem a composições (quadro 3) que se organizam em bandas, concretamente bandas contínuas de linhas paralelas horizontais, que delimitam, em regra, triângulos (1) e losangos (2) preenchidos internamente por linhas oblíquas, ou mais raramente verticais, colocados de forma sequencial e paralela aos bordos. Com idêntica organização, mas formando composições mais elaboradas, encontram-se triângulos invertidos e escalariformes (5) delimitados por bandas de linhas paralelas. 
Quadro 2. Elementos básicos da decoração tipo Carambolo nas cerâmicas da Beira Interior.

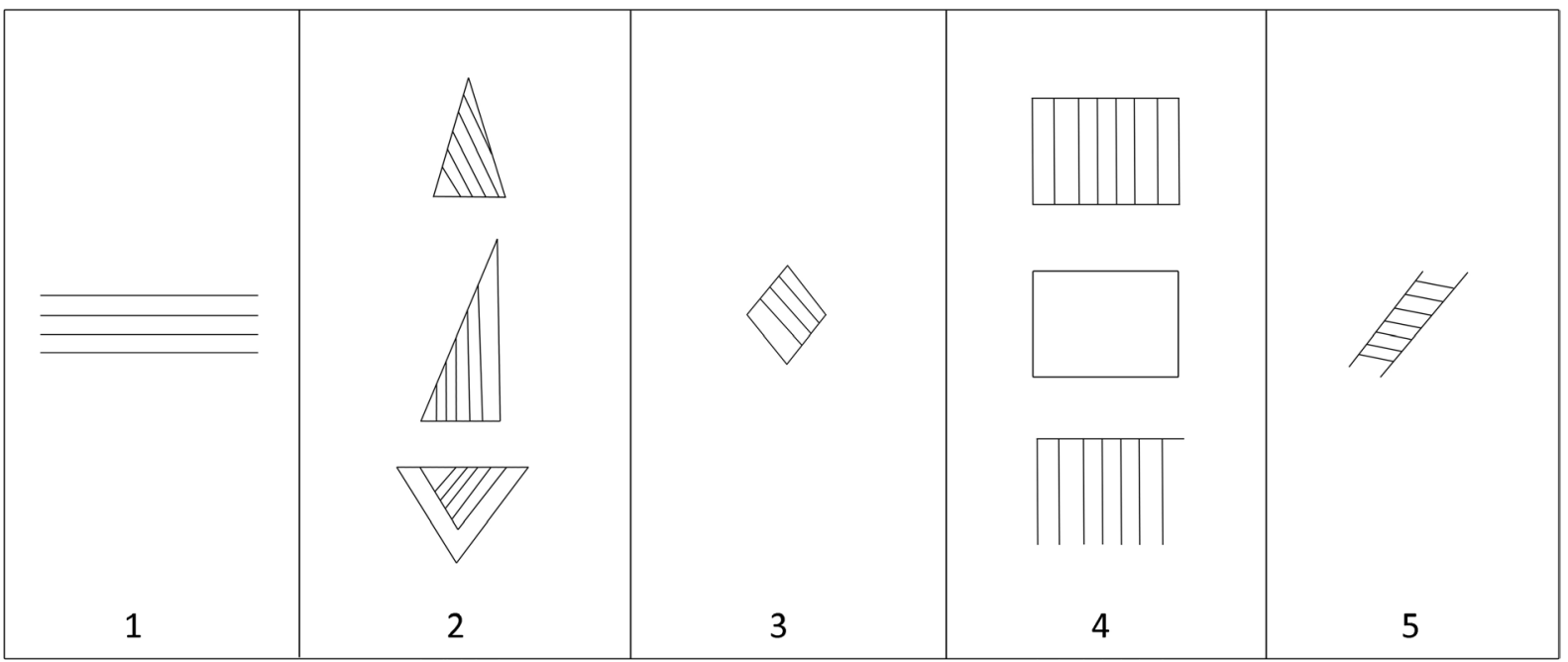

Essas bandas também se integram em composições metopadas, com losangos alternados por feixes de linhas verticais (3), ou com estas alternadas com espaços em reserva (4). É perceptível a existência de outras potenciais configurações, mas a parcialidade dos registos dificulta a sua descrição. Dominam, sem margem para dúvidas, as composições geométricas simples.

Será inconsequente alistar paralelos específicos de forma exaustiva para estes motivos e composições da Beira Interior, pois seriam muitos os casos a referir, nomeadamente no Baixo Guadalquivir, desde logo nos conjuntos de El Carambolo ou da Universidad Laboral de Sevilla (Carriazo 1973: 352-359; Buero Martínez e
Fernández Gómez 2010: 55-56 e fig. 5; Casado Ariza 2015: 117). Nas regiões mais próximas, como a Extremadura, mas igualmente a Meseta Ocidental, é esse mesmo universo decorativo, estritamente geométrico, que impera, como mostram os fragmentos de Valcorchero e Boquique já referidos (Almagro Gorbea 1977: 86, 96), os do Cerro del Castillo de Medellín I (Almagro Gorbea e Martín Bravo 1994: 112 e fig. 21), ou ainda os de Los Concejilles (Vilaça et al. 2012: 140 e fig. 17), entre outros. Nestes, a bibliografia que consultámos sugere algumas pistas que, todavia, não explorámos. Por exemplo, seria interessante confirmar o exemplar de El Castillo de Herguijuela (Ciudad Rodrigo) (Martín

Quadro 3. Composições decorativas nas cerâmicas tipo Carambolo da Beira Interior.

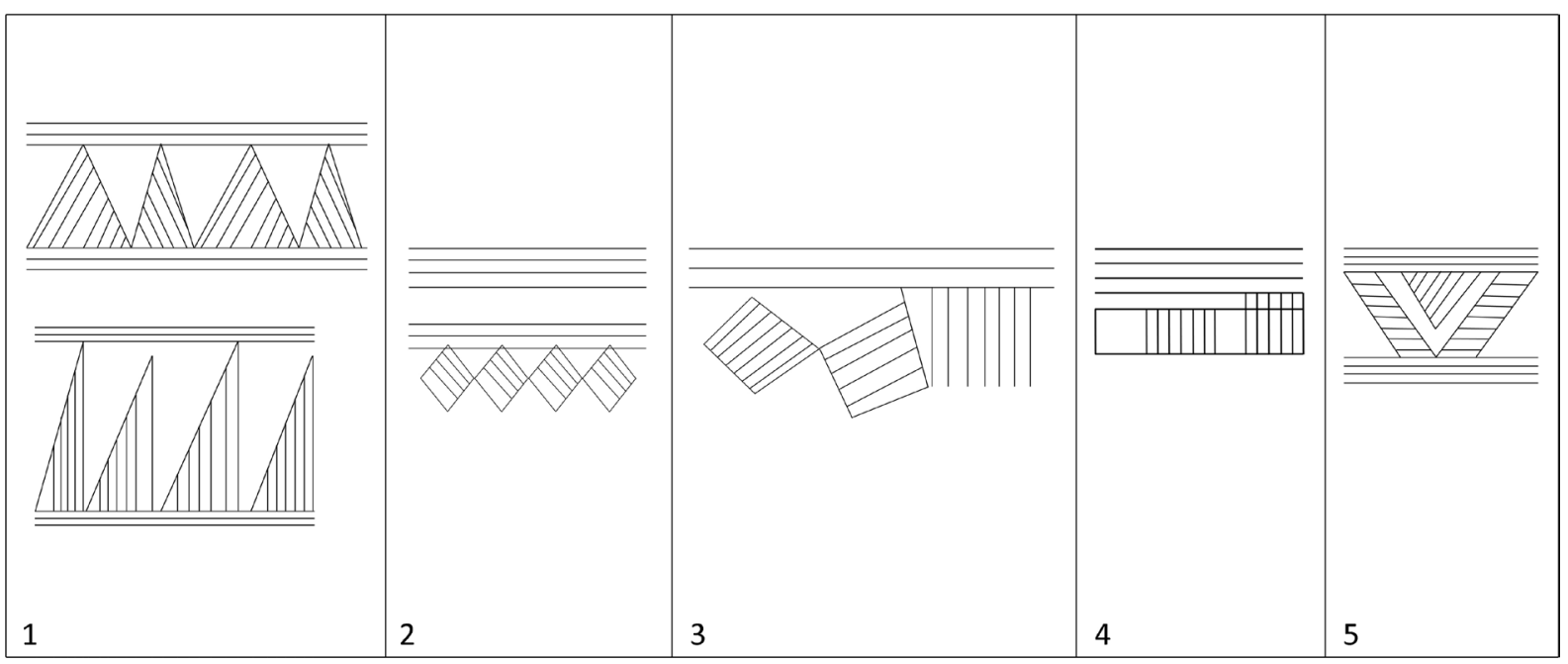


Benito e Martín Benito 1994: 119 e fig. 31) e compará-lo, atendendo à proximidade geográfica, com o conjunto de Vila do Touro.

Por outro lado, e atendendo aos motivos decorativos e sua organização, dificilmente poderemos considerar a cerâmica de tipo Carambolo absolutamente 'revolucionária' no contexto das demais cerâmicas de excepção da Beira Interior na transição do II para o I milénio a.C.

De facto, a matriz conceptual e estética, de base geométrica, consistindo em linhas rectas ou quebradas, faixas de linhas paralelas, triângulos, losangos, mais excepcionalmente quadrados/ rectângulos e escalariformes, que compilámos, também se regista entre outras cerâmicas coevas, como as de ornatos brunidos ou de tipo Lapa do Fumo (Vilaça 1995: 284, fig. 36; Osório 2013: 137-138, tabela 1), sucedendo o mesmo com as cerâmicas de tipo Baiões/ Santa Luzia, cuja decoração foi efectuada pós-cozedura ou com as pastas num extremo grau de secura. Consideramos, de certa forma, que a cerâmica de tipo Baiões/ Santa Luzia, de inequívoco e expressivo regionalismo, concretamente na Beira Alta, encontra a sua "homóloga" na cerâmica gravada, esgrafiada, incisa e até (incorretamente) dita, por vezes, grafitada, do Baixo Guadalquivir, que Casado Ariza também estudou (2015: 83).

Portanto, motivos e composições idênticos partilhados entre três categorias distintas de cerâmicas globalmente contemporâneas. Ademais, o próprio campo cromático, tão especial e peculiar nas cerâmicas de tipo Carambolo, não deixa de estar igualmente presente, com outra "roupagem" e, sobretudo, conseguido de outro modo, entre as cerâmicas de tipo Lapa do Fumo, entre as quais o contraste bicolor é, por vezes, igualmente excepcional (v.g. Vilaça 1995; Soares 2005; Osório 2013).

Em síntese, formas similares e motivos idênticos, sempre de cariz geométrico, a que se contrapõem técnicas decorativas díspares - pintura, ornatos brunidos, incisão - eis, de forma simples e sintética, o perfil das cerâmicas de prestígio do Bronze Final do Centro do território português, entre as quais (contam-se ainda entre as cerâmicas de prestígio da Beira Interior as cerâmicas de âmbito Cogotas I) as cerâmicas de tipo Carambolo têm direito a um (pequeno mas importante) lugar.

\subsection{Análise laboratorial da pigmentação das cerâmicas}

O reconhecimento da existência de pintura vermelha nestas cerâmicas foi acompanhado, desde o primeiro momento, pela pergunta: que substâncias ou pigmentos teriam sido utilizados? Óxidos de ferro, cinábrio, sangue, combinatória deste com algum daqueles, outros elementos? O trabalho de laboratório efectuado permitiu obter uma primeira resposta a essa questão.

Foram estudadas as amostras A (Argemela, fig. 6), C1 e C2 (Cachouça, fig. 5), M2 e M3 (Moreirinha, fig. 4-2 e 4-3) e V1, V2, V3 e V5 (Vila do Touro, fig. 7-1, 7-2, 7-3 e 7-5). Dessas, sete (A, C1, C2, M3, V1, V2 e V3) apresentam motivos executados com um pigmento vermelho em traços bem definidos e duas (M2 e V5) exibem pigmentação vermelha distribuída à superfície de forma irregular. Este último pigmento aparenta a mesma cor base que o presente nas outras amostras, mas com algumas zonas de tons amarelados, eventualmente devido a 'lavagem' ou efeito de líquidos. A superfície da cerâmica não é igual em todas as amostras, apresentando três delas (A, V1 e V2) cor amarelada, enquanto todas as outras a possuem muito escura.

Para se proceder à identificação dos materiais de que são compostos os pigmentos utilizados na pintura, recorreu-se às técnicas experimentais de análise por fluorescência de raios-X (XRF), difracção de raios-X (XRD) e espectroscopia micro-Raman ( $\mu$-Raman).

A primeira destas técnicas (XRF) permitiu executar uma análise elementar da superfície das amostras, através da utilização da aparelhagem Hitachi EA6000VX, a funcionar em modo de dispersão de energia e equipada com um detector semicondutor de deriva de silício Vortex e um gerador de raios-X com alvo de tungsténio (W) e com resolução entre 155 e 185 eV, para a transição $\mathrm{Mn}-\mathrm{K} \alpha$, podendo identificar a presença dos elementos químicos entre magnésio $(\mathrm{Mg})$ e urânio (U). As outras duas técnicas (respectivamente XRD e $\mu$-Raman) permitiram uma análise estrutural e molecular, através da utilização de um difractómetro de raios-X de pó Bruker D8 Advance (que funciona com radiação de $\mathrm{Cu}-\mathrm{K} \alpha$ e um detector de silício de deriva 1D-LynxEye) e de um espectrómetro de micro-Raman Jobin-Yvon T64000, com Laser de $\mathrm{Ar}^{+}$, funcionando a um comprimento de onda $\lambda=514 \mathrm{~nm}$, com resolução de 0,1 $\mathrm{cm}^{-1}$, um microscópio com uma objectiva de 50x e um detector multicanal (CCD) refrigerado e azoto líquido.

\subsubsection{Análise por XRF}

Em todas as amostras analisadas por XRF foi claro que o pigmento vermelho contém ferro $(\mathrm{Fe})$. Atente-se no excesso de $\mathrm{Fe}$ em pontos do pigmento, comparativamente com pontos fora do pigmento, em todas as amostras (em termos percentuais no Quadro 4 e em termos de 
Quadro 4. Distribuição percentual relativa dos elementos químicos detectados nas várias amostras estudadas.

\begin{tabular}{|c|c|c|c|c|c|c|c|c|c|}
\hline$\%$ & $\mathrm{Al}$ & $\mathrm{Si}$ & $\mathrm{P}$ & $\mathrm{S}$ & $\mathrm{Cl}$ & $\mathrm{K}$ & $\mathrm{Ca}$ & $\mathrm{Ti}$ & $\mathrm{Fe}$ \\
\hline A-vm & 22.7 & 14.9 & 1.6 & 2.2 & 0.8 & 3.4 & 3.1 & 1.7 & 48.1 \\
\hline A-p & 21.6 & 38.1 & 2.2 & 1.5 & 0.6 & 5.9 & 6.2 & 2.2 & 20.9 \\
\hline M2-vm & 23.5 & 27.1 & 10.0 & 0.0 & 1.2 & 5.8 & 2.7 & 1.8 & 26.9 \\
\hline M2-p & 26.1 & 41.3 & 3.4 & 0.0 & 0.2 & 5.1 & 2.6 & 1.7 & 18.9 \\
\hline M3-vm & 22.1 & 23.1 & 1.7 & 0.0 & 0.8 & 7.8 & 2.8 & 2.9 & 38.0 \\
\hline M3-p & 26.4 & 38.5 & 2.6 & 1.0 & 0.4 & 8.7 & 3.1 & 2.4 & 16.4 \\
\hline C1-vm & 19.0 & 29.4 & 2.5 & 1.5 & 1.2 & 6.8 & 2.4 & 2.1 & 33.7 \\
\hline C1-p & 25.3 & 39.1 & 3.9 & 1.8 & 0.7 & 9.8 & 3.0 & 3.0 & 15.6 \\
\hline C2-vm & 17.8 & 22.8 & 0.4 & 2.0 & 0.7 & 6.0 & 1.8 & 1.9 & 45.6 \\
\hline C2-p & 22.8 & 46.4 & 1.0 & 1.0 & 0.5 & 9.3 & 3.5 & 3.1 & 12.1 \\
\hline V1-vm & 23.2 & 28.2 & 6.1 & 1.9 & 1.0 & 9.0 & 3.0 & 2.3 & 24.5 \\
\hline V1-p & 26.8 & 35.2 & 7.7 & 1.3 & 0.5 & 12.1 & 3.0 & 2.3 & 10.6 \\
\hline V2-vm & 24.9 & 34.9 & 2.4 & 0.0 & 0.3 & 8.4 & 2.3 & 3.0 & 22.7 \\
\hline V2-p & 25.2 & 41.7 & 3.9 & 0.0 & 0.7 & 10.8 & 2.4 & 2.4 & 12.4 \\
\hline V3-vm & 19.4 & 34.4 & 4.6 & 0.0 & 1.1 & 6.4 & 3.1 & 3.1 & 26.7 \\
\hline V3-p & 21.5 & 51.1 & 2.9 & 0.0 & 1.0 & 7.9 & 2.0 & 2.5 & 8.5 \\
\hline V5-vm & 24.5 & 31.3 & 4.0 & 0.0 & 0.8 & 5.8 & 4.1 & 4.1 & 24.1 \\
\hline V5-p & 24.2 & 39.7 & 3.7 & 0.0 & 0.4 & 8.7 & 3.5 & 3.9 & 15.5 \\
\hline
\end{tabular}

Note-se que os sufixos vm e p dizem respeito a pigmento vermelho e a pasta ou engobe, respectivamente. As amostras são identificadas por A - Argemela, M - Moreirinha, C - Cachouça e V - Vila do Touro.

contagens por segundo no Quadro 5, comparem-se os sinais dos pigmentos $-v m$ e da pasta ou engobe $-p)$. Note-se que o sinal proveniente do Fe não provém apenas do pigmento vermelho, uma vez que também é detectado em pontos das amostras sem pigmento e a penetração dos raios-X é superior à sua espessura, detectando-se sinais provenientes do material que se encontra por baixo. É igualmente claro que a cerâmica e seu revestimento (engobe) também contêm Fe. Além disso, e pelo mesmo raciocínio usado para o caso da pigmentação, a quantidade relativa de alumínio $(\mathrm{Al})$, silício $(\mathrm{Si})$, fósforo $(\mathrm{P})$, potássio $(\mathrm{K})$ e cálcio $(\mathrm{Ca})$, em pontos sem pigmento é claramente superior ao conteúdo em pontos com pigmento (em termos percentuais no quadro 4 e em termos de contagens por segundo no quadro 5, comparem-se os sinais dos pigmentos -vm e da pasta ou engobe $-p$ ), atribuindo-se a existência destes elementos essencialmente à cerâmica e seu revestimento (não se exclui a sua presença no pigmento, mas caso isso se verifique, será em menores quantidades). Verificou-se a existência em algumas das amostras de enxofre $(\mathrm{S})$, cloro $(\mathrm{Cl})$ e titânio (Ti), comuns em cerâmicas, sem existência preferencial nas diferentes camadas de pigmento e pasta ou engobe. Como hipótese (a confirmar pelas outras técnicas), podemos avançar uma composição dos pigmentos baseada em ocres vermelhos (à base de óxidos de ferro do tipo hematite), e alumino silicatos e outros compostos típicos das cerâmicas como a sílica, para a pasta e engobe.

$\mathrm{Na}$ fig. 13 apresenta-se uma imagem da amostra da Argemela e na fig. 16 apresentam-se os espectros de XRF da amostra da Argemela (A) em pontos sobre o pigmento vermelho (A-vm) e sobre a pasta (A-p), onde se salienta a maior intensidade dos picos referentes ao Fe no primeiro relativamente ao segundo e o inverso no que concerne os picos referentes aos outros elementos químicos assinalados. 
Quadro 5. Distribuição em termos de contagens por segundo (cps) dos elementos químicos detectados nas várias amostras estudadas.

\begin{tabular}{|c|c|c|c|c|c|c|c|c|c|}
\hline cps & $\mathrm{Al}$ & $\mathrm{Si}$ & $\mathrm{P}$ & $\mathrm{S}$ & $\mathrm{Cl}$ & $\mathrm{K}$ & $\mathrm{Ca}$ & $\mathrm{Ti}$ & $\mathrm{Fe}$ \\
\hline $\mathrm{A}-\mathrm{vm}$ & 6.0 & 17.4 & 6.1 & 0.4 & 0.4 & 5.2 & 7.0 & 16.2 & 785.6 \\
\hline $\mathrm{A}-\mathrm{p}$ & 11.1 & 74.6 & 9.7 & 0.3 & 0.3 & 9.8 & 14.3 & 18.4 & 393.2 \\
\hline M2-vm & 6.7 & 29.8 & 26.0 & 0.0 & 0.4 & 5.9 & 4.1 & 10.3 & 322.5 \\
\hline M2-p & 10.6 & 57.2 & 10.1 & 0.0 & 0.1 & 5.9 & 4.6 & 11.0 & 280.1 \\
\hline M3-vm & 6.6 & 29.0 & 6.2 & 0.0 & 0.4 & 11.2 & 6.1 & 21.4 & 562.8 \\
\hline M3-p & 14.9 & 73.4 & 11.0 & 0.2 & 0.3 & 14.0 & 7.6 & 19.6 & 307.0 \\
\hline C1-vm & 6.0 & 40.0 & 8.6 & 0.3 & 0.5 & 9.1 & 5.0 & 16.0 & 506.3 \\
\hline C1-p & 13.9 & 72.0 & 15.2 & 0.3 & 0.3 & 14.1 & 6.5 & 20.7 & 210.9 \\
\hline C2-vm & 4.5 & 26.7 & 2.1 & 0.3 & 0.3 & 8.1 & 3.9 & 15.3 & 677.0 \\
\hline C2-p & 12.2 & 84.9 & 4.5 & 0.2 & 0.3 & 12.6 & 7.0 & 20.3 & 192.0 \\
\hline V1-vm & 8.5 & 39.5 & 20.5 & 0.3 & 0.4 & 11.4 & 5.7 & 15.0 & 348.0 \\
\hline V1-p & 14.8 & 62.3 & 28.7 & 0.2 & 0.3 & 16.5 & 6.4 & 14.7 & 165.7 \\
\hline V2-vm & 9.3 & 48.1 & 8.0 & 0.0 & 0.2 & 10.7 & 4.7 & 19.3 & 330.6 \\
\hline V2-p & 13.5 & 73.9 & 14.3 & 0.0 & 0.3 & 14.7 & 5.4 & 16.2 & 199.1 \\
\hline V3-vm & 6.4 & 46.7 & 14.2 & 0.0 & 0.4 & 7.7 & 5.5 & 19.8 & 366.0 \\
\hline V3-p & 9.5 & 76.6 & 8.1 & 0.0 & 0.3 & 8.0 & 3.3 & 12.7 & 112.1 \\
\hline V5-vm & 9.1 & 43.9 & 13.3 & 0.0 & 0.4 & 7.7 & 7.8 & 27.4 & 352.4 \\
\hline V5-p & 11.3 & 64.7 & 12.7 & 0.0 & 0.2 & 11.5 & 6.9 & 24.7 & 232.8 \\
\hline
\end{tabular}

Note-se que os sufixos vm e p dizem respeito a pigmento vermelho e a pasta ou engobe, respectivamente. As amostras são identificadas por A - Argemela, M - Moreirinha, C - Cachouça e V - Vila do Touro.

\subsubsection{Análise por XRD}

Uma vez que a análise por XRF é uma análise de composição química elementar, foi necessário executar outras análises complementares de modo a confirmar a composição da pigmentação existente sobre as amostras de cerâmica, que se verificou conterem ferro.

Seleccionaram-se quatro amostras para executar estas análises: A, C2, V1 e V2. Tendo em conta a geometria do feixe de raios-X incidente nas amostras (linear, de comprimento de cerca de $1 \mathrm{~cm}$ e largura de alguns milímetros), a escolha incidiu nas amostras com uma dimensão adequada e com a superfície o mais plana possível. Dos resultados obtidos, salientam-se as conclusões que se apresentam de seguida.

Em todas as amostras é evidente a presença de quartzo, em particular nas amostras de Vila do Touro, V1 e V2, que apresentam um engobe a cobrir a pasta. Este composto é muito característico de cerâmicas. Como exemplo, apresenta-se na fig. 17 o difractograma da amostra A.

A presença de hematite (ou um óxido de ferro semelhante) é evidente na amostra A e um pouco menos nas de Vila do Touro. Quanto à amostra C2 não se detectou este composto, talvez pelo facto de o pigmento vermelho estar presente em pequena quantidade relativamente à pasta na área coberta pelo feixe de raios-X.

Nas amostras A e C2 aparecem evidências de material amorfo, pela presença de bandas largas nas regiões de $15^{\circ}$ e $22^{\circ}$, o que não acontece nas amostras V1 e V2, talvez por estas últimas apresentarem uma camada de engobe, de superfície mais plana e lisa.

Detectou-se também a presença de outros compostos característicos de cerâmica, silicatos como albite, kanoite, anortite, lizardite, entre outros (fig. 17). 


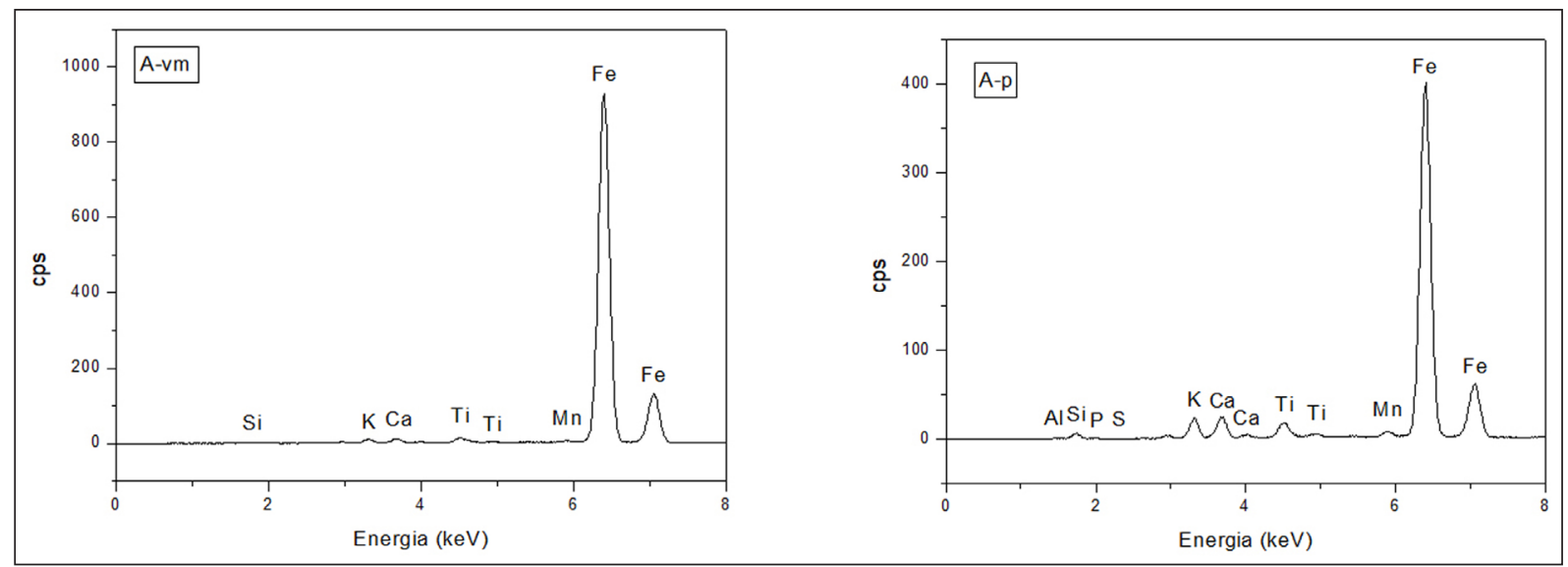

Figura 16. Espectros XRF sobre pontos do pigmento A-vm e sobre o engobe A-p. Sobressai a maior intensidade dos picos referentes ao $\mathrm{Fe}$ no primeiro ponto e maior intensidade dos picos referentes aos outros elementos, no segundo ponto.

\subsubsection{Análise por espectroscopia $\mu$-Raman}

De modo a esclarecer a composição do pigmento vermelho presente na amostra $\mathrm{C} 2$, assim como em outras amostras com uma superfície de relevo acentuado (o que dificulta o acesso para as outras técnicas), procedeu-se à sua análise usando a técnica espectroscópica de m-Raman, com a qual se pode identificar a composição molecular em áreas de alguns micrómetros.
As amostras analisadas por esta técnica foram A, M2, M3, M5, C1, C2, V1, V2, V3 e V5 e os espectros dos pigmentos estão representados na fig. 18 .

O espectro da amostra A apresenta picos a cerca de $120 \mathrm{~cm}^{-1}, 220 \mathrm{~cm}^{-1}, 290 \mathrm{~cm}^{-1}$ e $405 \mathrm{~cm}^{-1}$, típicos de óxidos de ferro do tipo da hematite, correspondente a ocre vermelho. A amostra M2 apresenta picos desviados para valores mais baixos, a $120 \mathrm{~cm}^{-1}, 215$ $\mathrm{cm}^{-1}, 275 \mathrm{~cm}^{-1}$ e $405 \mathrm{~cm}^{-1}$. Todas as outras amostras
Figura 17. Difractograma da superfície da amostra A, mostrando a existência de hematite (a), quartzo (b), albite (c), anortite (d), kanoite (e) e lizordite (f).

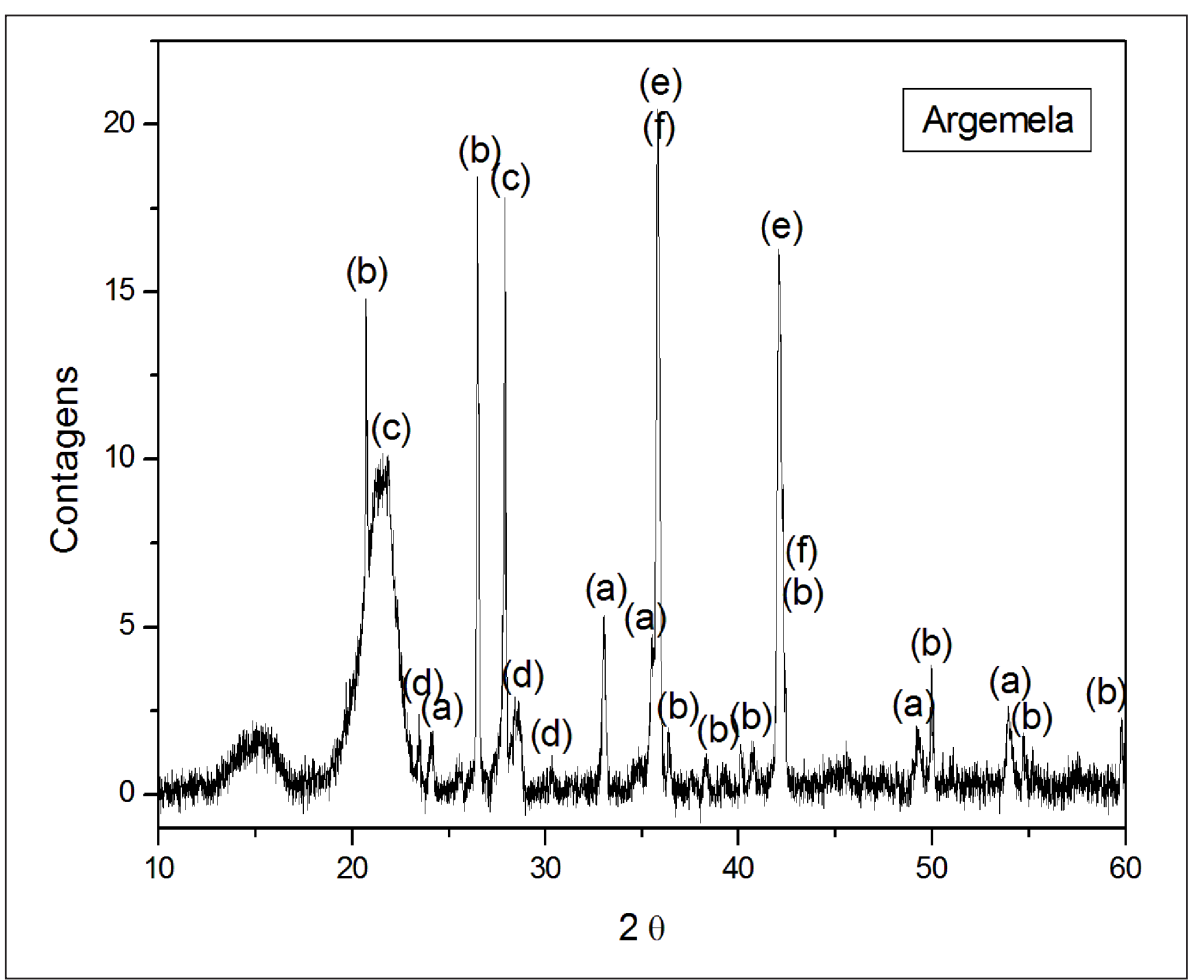




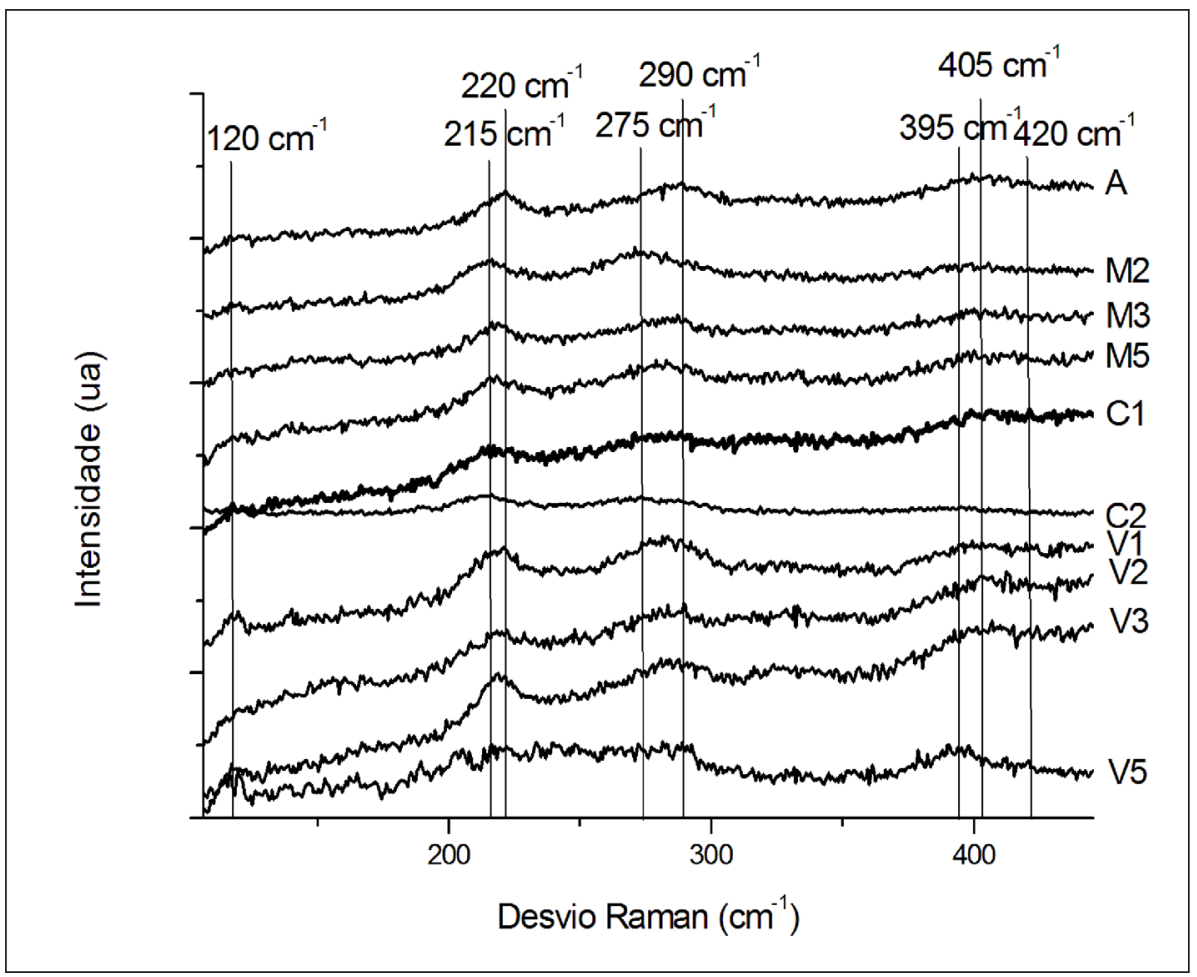

Figura 18. Espectros m-Raman das amostras A, $\mathrm{M} 2, \mathrm{M} 3, \mathrm{M} 5, \mathrm{C} 1, \mathrm{C} 2, \mathrm{~V} 1$, V2, V3 e V5.

apresentam uma mistura de bandas idênticas às das amostras A e M2.

As amostras A, M3, M5 e V3 têm uma tonalidade vermelha escura (material compacto e bem fixo), enquanto as outras apresentam uma tonalidade alaranjada (M3 e V5 são laranja claro, sendo o pigmento espalhado aleatoriamente pela superfície em tufos) (fig. 19).

Assim, tendo em conta que os espectros dos pigmentos das amostras mais alaranjadas contêm picos com desvios relativamente aos típicos do ocre vermelho, é revelador de uma transformação de estrutura, por acção química de materiais com que estiveram em contacto ou com que interagiram, como por exemplo provocando a sua lavagem (caso de M3 e V5).

Pode concluir-se que o pigmento original seria ocre vermelho (óxido de ferro em mistura com sílica) e que se alterou em alguns dos casos.

\subsection{Cerâmicas viajantes?}

Não é nosso intuito analisar aqui a questão da origem última das cerâmicas de tipo Carambolo, que tem conduzido a leituras de distintos matizes tendo como pano de fundo, mesmo para produções peninsulares, o fenómeno geral das cerâmicas geométricas do mundo mediterrâneo mais oriental.

A questão que nos colocamos e para a qual não dispomos de resposta inequívoca diz respeito à origem das cerâmicas de tipo Carambolo da Beira Interior. Aliás, não afastamos a possibilidade de, em vez de uma, existirem duas ou mais respostas. Sem análises às pastas, que não foram efectuadas, desejavelmente enquadradas num projecto em rede entre investigadores e que integre outras amostras, essas respostas ficarão em aberto. O diálogo com o laboratório, iniciado neste estudo, deverá ter, assim, continuidade.

Numa observação macroscópica e com o conhecimento que temos do universo cerâmico proto-histórico daquela região, poderemos dizer que, no geral, os diversos fragmentos que manipulámos apresentam pastas, fabricos e acabamentos similares aos das produções regionais. Também as formas são familiares ao repertório cerâmico beirão, corroborando essa mesma tendência localista ou regionalista. Só dois dos fragmentos de Vila do Touro (fig. 7-1, 7-2 e 12) são manifestamente distantes, pelo que admitimos como muito provável a sua proveniência exógena (inclusive mediterrânea ?) num contexto de troca de bens ou de circulação de pessoas, nomeadamente no âmbito da exogamia, com ensino e aprendizagem inter-geracional, numa linhagem 


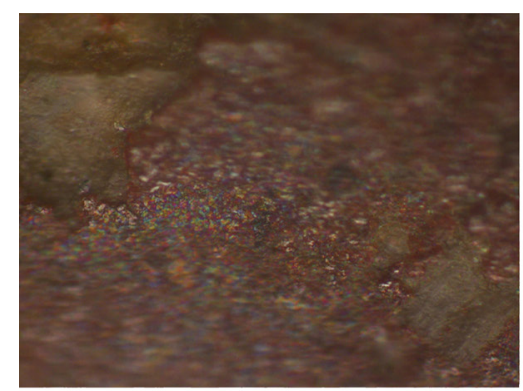

(a)

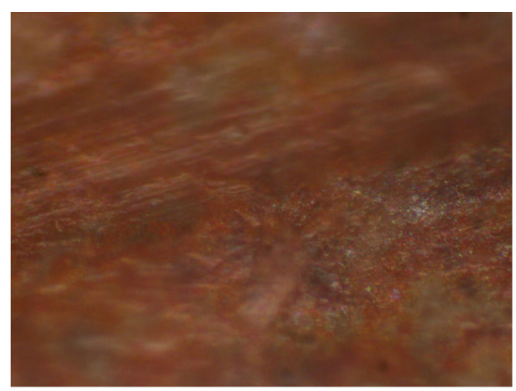

(b)

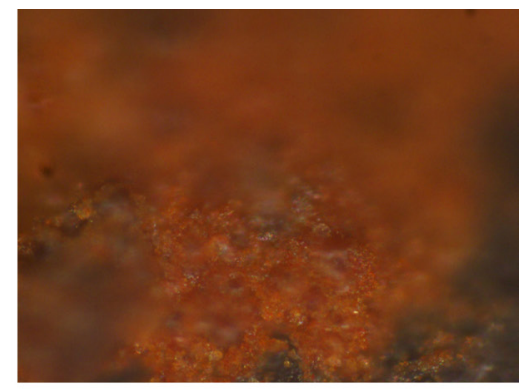

(c)

Figura 19. Imagens micrométricas de 3 amostras exemplificativas da estrutura do pigmento. Enquanto a amostra A apresenta uma consistência de pigmento vermelho, bem coeso com o suporte, a amostra V1 apresenta um pigmento mais alaranjado, embora também coeso com o suporte, enquanto que a amostra V5 apresenta zonas com pigmento mais laranja claro e disperso em tufos.

feminina, modelo que tem tido boa receptividade entre diversos investigadores.

Todavia, não descartamos essa mesma situação para os demais fragmentos, embora não seja de afastar por completo uma origem beirã para tais casos, hipótese que carece também de fundamentação segura. De todo o modo, o conjunto, como sublinhámos já, é heterogéneo, situação a que poderia corresponder mais do que uma origem, ou, ao invés, distintas recriações locais. Neste sentido, a emulação destas cerâmicas no contexto das comunidades é igualmente plausível, tal como o é a possibilidade de esse fenómeno cultural ter sido acompanhado da aplicação intencional de motivos pintados sobre outros pré-existentes em cerâmicas com certeza de produção local, conforme sugerem os exemplares da Moreirinha e da Quinta das Rosas (mais incerto no de Vila do Touro).

Em todo o caso, o(a)s oleiro(a)s da Beira Interior do último quartel do II milénio a.C. e de inícios do seguinte não eram, manifestamente, pintores vasculares, o que não significa que não tivessem ensaiado, pontualmente, a técnica, ou presenciado como se fazia. Ou, será que terão, tão-só, revelado deslumbramento face a um novo efeito estético nunca tecnicamente compreendido? Em termos sociais, o reconhecimento dessas cerâmicas como bens distintos e de distinção, por conseguinte, especiais, não destoa daquilo que nos dizem duas inquestionáveis evidências: o carácter residual dos registos, a novidade estética e decerto conceptual a eles associada.

Faz assim sentido que encaremos as cerâmicas de tipo Carambolo na Beira Interior como testemunho, tal como indicam outros artefactos (Vilaça 2008b; 2013a), de abertura deste mundo interior (nunca será de mais lembrar a importância nuclear do minério e metal das suas terras, como o estanho, o ouro e o cobre) a outros mundos, neste caso (e mais uma vez) ao Baixo Guadalquivir, em inícios do I milénio a.C. O olhar dos seus habitantes, ou de quem, por e entre eles, agia e tomava a condução do processo histórico na dialéctica social, estendia-se, através de redes de trocas, de contactos ou de viagens, àquelas terras distantes. Por essa via, metaforicamente, também as 'águas do Mediterrâneo', como que numa 'onda' suave mas alastrada, banharam estas latitudes mais setentrionais. E, como 'onda', em movimento, avançando e dissolvendo-se a seguir.

\subsection{Usos, simbologias, conjecturas}

Como ficou perfeitamente claro, todos os contextos destas cerâmicas na Beira Interior reportam-se a âmbito dito normalmente doméstico, no sentido de lugares habitados, e, justamente por isso, também com espaço à encenação de actividades rituais indissociáveis do modo de ser, de estar e de percepcionar $\mathrm{n}(\mathrm{o})$ mundo por parte dessas sociedades agrafas e arcaicas. Também em nenhum dos casos podemos falar em espaços sagrados discretos, ainda que na Cachouça convirjam diversos testemunhos, construídos, adaptados ou tão-só artefactuais, susceptíveis de ambientes configurando essa tendência (Vilaça 2007a).

A manipulação destas cerâmicas, conjuntamente com outros artefactos, num jogo de acções ritualizadas, difíceis de vislumbrar, parece ser perfeitamente possível no campo das hipóteses que as evidências permitem colocar. Assim, fosse em cerimónias mais performativas, fosse em acções menos encenadas, mas todas elas carregadas de sentido(s) - em rituais de passagem, em rituais de comensalidade, por exemplo -, as cerâmicas de tipo Carambolo adequavam-se perfeitamente ao desempenho de um papel específico nessa moldura ritual. 
Assim, admite-se como hipótese mais plausível o uso destas cerâmicas para conter substâncias raras e de elevado valor, especificamente protegidas e conservadas em recipientes eles próprios excepcionais, seja pela sua raridade, seja pelos óbvios custos (técnicos e sociais) de produção inerentes, seja ainda pela simbologia - qualquer que ela tenha sido - dos motivos vermelhos da sua decoração. Não dispomos de pistas relativas à natureza da(s) substância(s) que poderiam ter contido, embora não se recuse que pudessem ter sido, eventualmente, de índole alcoólica, conforme defendeu Mariano Torres para as cerâmicas da Andaluzia ocidental, também elas maioritariamente de contextos domésticos (Torres 2002: 135, 166).

Conforme notámos em 4.2.2., ao nível da decoração, o figurativo, presente em determinadas cerâmicas de tipo Carambolo do Baixo Guadalquivir, nomeadamente em El Carambolo, tem permitido leituras de âmbito religioso especificamente na órbita da cultuação a Tanit/ Astarté. Essas leituras são de afastar por completo no caso do conjunto que estudámos, desde logo porque a decoração figurativa, por vezes muito barroca, é aqui inexistente, mas também porque os contextos arqueológicos e culturais o impedem.

A mensagem simbólica inerente a esses e a certos motivos geométricos, estes a imperar no conjunto aqui estudado, permitiria discorrer largamente sobre o significado antropológico e religioso dos símbolos, caminho que, todavia, não percorreremos aqui, até porque já outros o fizeram (v.g. Buero Martínez 1984; Buero Martínez e Fernández Gómez 2010: 60-63; Casado Ariza 2015: 230-244).

$\mathrm{Na}$ verdade, algum constrangimento sentimos face à absoluta presença de motivos "geometrizantes" no conjunto estudado, cujo significado e simbologia potencialmente subjacentes oferecem um amplo espectro, incluindo o da transposição de motivos inspirados nos que ornamentavam tecidos sumptuários orientais, conforme advogaram alguns investigadores, eles próprios inspirados na hipótese matricial (contemplando também madeiras pintadas) lançada por Buero Martínez (1987: 43, 45), como o fez Marisa Ruiz-Gálvez a partir das cerâmicas pintadas de Peña Negra I (Ruiz-Gálvez Priego 1993: 56). No fundo, trata-se de motivos dominados por gramática pouco "dialogante" com o investigador, porque de timbre trans-temporal, inter-epocal e supra-regional, de índole arqueológica, etnográfica e etno-histórica.

Vimos também atrás que esses motivos, como triângulos, losangos, bandas de linhas, escalariformes, etc., encontram-se amplamente divulgados na região, muito em especial na decoração de cerâmicas como as de tipo Lapa do Fumo e de tipo Baiões, todas elas de excepção. Neste sentido, admitimos que, mais do que a nova técnica, a pintura, mais do que a gramática decorativa, com motivos não exclusivos de si mas partilhados por outros grupos cerâmicos, terá sido a cor, uma nova cor, a poderosa cor vermelha, a ditar outras formas de comunicação com simbologia inovadora nos respectivos contextos, não obstante (e talvez por isso) o ancestral significado da cor vermelha, transformador, regenerador, vinculado ao sangue, à vida.

Ainda assim, no final, importa o todo, motivos e cor num só corpo, que é também o da forma que corporiza o recipiente cerâmico, frequentemente brilhante. Essas cerâmicas continham bens, sólidos ou líquidos, frios ou quentes, com sabor, com cheiro, também eles com cor. $\mathrm{O}$ efeito visual, a dimensão sensorial de conjunto seriam enormes, ajudando a estreitar as relações entre essas cerâmicas e as pessoas (ou algumas pessoas) que as manipulavam. Se a eficácia dos objectos é determinada não só pelo seu efeito imediato sobre o observador, mas também após esse efeito, ou seja, pela forma como esse efeito é retido na memória (Jones 2007: 155), então as cerâmicas de tipo Carambolo seriam altamente eficazes, em acção, e para além dela. Materiais com esta capacidade de se prolongarem para além deles próprios, de se excederem a eles mesmos, tendem a ser resilientes ao tempo, tendem a ter vida longa.

\subsection{Cronologias e datas de Radiocarbono}

Este sub-capítulo incide sobre os resultados obtidos a partir de um pequeno conjunto de doze datas de radiocarbono, cinco das quais inéditas (quadros 6 e 7), respeitantes a contextos da Beira Interior (ver ponto 2) onde se verificou a presença de cerâmica de tipo Carambolo. Outras datas reportáveis ao Bronze Final e à Idade do Ferro não foram aqui consideradas por corresponderem a níveis ou contextos que, embora culturalmente idênticos, não continham cerâmicas de tipo Carambolo.

O conjunto integra ainda duas datas do Cerro de San Pelayo (Martinamor, Salamanca), de onde provém uma taça com decoração geométrica pintada a vermelho vinoso, recolhida no nível VI, o único considerado em posição original e que os autores reportam a meados do séc. IX a.C. Existe uma terceira data (GrN-13969: $2910 \pm 140$ BP) que os investigadores não valorizam, seja pelo grande desvio-padrão, seja por se reportar ao nível V com terras oriundas de outro lado (Benet 1990; 
Quadro 6. Datações 14Carbono de níveis com presença de cerâmica de tipo Carambolo

(Centro Interior de Portugal e Meseta Norte Ocidental)

\begin{tabular}{|c|c|c|c|c|c|}
\hline Sítios & Referência Lab. & $\begin{array}{c}\text { Data }{ }^{14} \mathrm{C} \\
\text { (BP) }\end{array}$ & Contexto & Amostra & $\begin{array}{c}\text { Referência } \\
\text { bibliográfica }\end{array}$ \\
\hline Moreirinha & $\begin{array}{l}\text { ICEN-835 } \\
\text { OxA-4085 } \\
\text { ICEN-834 } \\
\text { GrN-19659 }\end{array}$ & $\begin{array}{l}2910 \pm 45 \\
2780 \pm 70 \\
2940 \pm 45 \\
2785 \pm 15\end{array}$ & $\begin{array}{l}\text { A6 } 02 \\
\text { C5 02-lareira } 2 \\
\text { A6 } 03 \\
\text { A6 } 03\end{array}$ & $\begin{array}{l}\text { Carvão } \\
\text { Carvão } \\
\text { Carvão } \\
\text { Carvão }\end{array}$ & Vilaça, 1995 \\
\hline Cachouça & $\begin{array}{l}\text { Sac-1929 } \\
\text { Sac-1931 } \\
\text { CSIC-1286 }\end{array}$ & $\begin{array}{l}2760 \pm 80 \\
2690 \pm 60 \\
2998 \pm 33\end{array}$ & $\begin{array}{l}\text { L'10/11 } 02 \text { base } \\
\text { L'10/11 } 02 \text { base } \\
\text { I'15 } 03\end{array}$ & $\begin{array}{l}\text { Carvão } \\
\text { Carvão } \\
\text { Carvão }\end{array}$ & Inéditas \\
\hline Vila do Touro & $\begin{array}{l}\text { Sac-3033 } \\
\text { Sac-3034 }\end{array}$ & $\begin{array}{l}2710 \pm 35 \\
2680 \pm 45\end{array}$ & $\begin{array}{l}\text { E4 } 04 \\
\text { E4 } 02\end{array}$ & $\begin{array}{l}\text { Carvão (Quercus) } \\
\text { Grãos de Trigo }\end{array}$ & Inéditas \\
\hline Quinta das Rosas & Sac-1964 & $2810 \pm 40$ & & Carvão & Valera, 2008 \\
\hline Cerro de San Pelayo & $\begin{array}{l}\text { GrN-13970 } \\
\text { GrN-13971 }\end{array}$ & $\begin{array}{l}2715 \pm 30 \\
2660 \pm 30\end{array}$ & $\begin{array}{l}\text { VI } \\
\text { VI }\end{array}$ & $\begin{array}{l}\text { Carvão } \\
\text { Carvão }\end{array}$ & Benet, 1990 \\
\hline
\end{tabular}

Quadro 7. Calibração das datas convencionais de radiocarbono fazendo uso das curvas IntCal13 (amostras terrestres) (Reimer et al., 2013), do programa OxCal (Bronk Ramsey, 2001) e de uma estatística bayesiana, com um modelo de Sequência com duas Fases (Bronk Ramsey, 2009).

\begin{tabular}{|c|c|c|c|c|c|}
\hline \multirow{2}{*}{ Ref. Lab. } & \multirow{2}{*}{$\begin{array}{c}\text { Data }{ }^{14} \mathrm{C} \\
\text { (BP) }\end{array}$} & \multicolumn{2}{|c|}{ Data calibrada (cal BC) } & \multicolumn{2}{|c|}{ Data modelada (cal BC) } \\
\hline & & $1 \sigma$ & $2 \sigma$ & $1 \sigma$ & $2 \sigma$ \\
\hline \multicolumn{4}{|c|}{ Fronteira Inicial } & $1292-1140$ & $1455-1083$ \\
\hline CSIC-1286 & $2998 \pm 33$ & $1284-1132$ & $1381-1121$ & $1244-1122$ & $1285-1054$ \\
\hline ICEN-835 & $2910 \pm 45$ & $1192-1021$ & $1231-945$ & $1158-1017$ & $1218-976$ \\
\hline OxA-4085 & $2780 \pm 70$ & $1004-842$ & $1112-809$ & $1024-893$ & $1118-849$ \\
\hline ICEN-834 & $2940 \pm 45$ & $1215-1058$ & 1270-1009 & $1183-1053$ & $1257-1006$ \\
\hline GrN-19659 & $2785 \pm 15$ & $972-906$ & $1001-896$ & $974-907$ & $995-900$ \\
\hline Sac-1964 & $2810 \pm 40$ & $1009-913$ & $1073-843$ & $1007-920$ & $1106-891$ \\
\hline \multicolumn{4}{|c|}{ Fronteira Bronze Final / Idade do Ferro } & $911-834$ & $933-821$ \\
\hline Sac-1929 & $2760 \pm 80$ & $996-830$ & $1119-797$ & $881-817$ & $906-806$ \\
\hline Sac-1931 & $2690 \pm 60$ & $896-806$ & $993-787$ & $888-813$ & $900-804$ \\
\hline Sac-3033 & $2710 \pm 35$ & $895-823$ & $918-806$ & $888-816$ & $897-811$ \\
\hline Sac-3034 & $2680 \pm 45$ & $894-803$ & $915-795$ & $889-811$ & $896-806$ \\
\hline GrN-13970 & $2715 \pm 30$ & $895-829$ & $913-810$ & $887-819$ & $898-812$ \\
\hline GrN-13971 & $2660 \pm 30$ & $832-801$ & $895-794$ & $842-806$ & $895-802$ \\
\hline \multicolumn{4}{|c|}{ Fronteira Final } & $838-789$ & $890-764$ \\
\hline
\end{tabular}


López Jiménez 2003: 137). Justificamos a sua inclusão nesta análise não obstante tratar-se de exemplar que envolve outras problemáticas mais gerais, inerentes ao complexo universo das cerâmicas pintadas pós-cozedura, nomeadamente de tipo Medellín, por ser o único contexto datado nesta área vizinha à Beira Interior, aliás também o único aqui contemplado que poderia ter sido de natureza funerária (López Jiménez 2003: 137). Mas é certo que a discussão desta problemática, ainda insuficientemente conhecida em todos os seus contornos, ultrapassa claramente os parâmetros deste texto, nos objetivos e no espaço disponível.

Como aludimos no início, um dos problemas posto a nu pela historiografia das cerâmicas de tipo Carambolo incide na sua cronologia, com tomadas de posição distintas, o que não significa necessário erro de uma e óbvio acerto de outra. Os resultados que ora disponibilizamos, suportados por datas de radiocarbono, até aqui praticamente arredadas da discussão desta categoria de cerâmicas, não deixam de ir, até certo ponto - mas só até certo ponto - ao encontro dessas propostas.

Recordemos, resumidamente, as posições que advogam cronologias altas (v.g. Almagro Gorbea 1977: 124, 459; Bendala 1979: 35, 1991; Ruiz Mata 198485: 242; Torres Ortiz 2002: 133) e as que perseguem, e encontram por vezes, reconhecido fundamento para baixar as cronologias (v.g. Buero 1984; Amores 1995: 166; Casado Ariza 2003: 288; 2015: 244). Para outro desenvolvimento do assunto, vejam-se, por exemplo, as sínteses de Mariano Torres (2002:132-134) e de Casado Ariza (2003; 2015: 87-92). Estas propostas, que resultam de cronologias arqueológicas, poderão remontar, as primeiras, aos sécs. X-IX a.C., mas centrando-se neste último e na primeira metade do VIII a.C., e as segundas chegam a alcançar o séc. VII a.C.

As datas de 14Carbono agora reunidas afastam claramente as cronologias baixas e recentram as altas, não obstante alguns problemas de fiabilidade que essas datas também encerram. Com efeito, essa falta de fiabilidade não resulta das datas em si - note-se que foram obtidas em quatro laboratórios diferentes (quadro 6) e, aparentemente, não existe qualquer incompatibilidade entre elas -, mas sim do tipo de amostra utilizado. Apenas uma amostra, respeitante a Vila do Touro, foi de um material de vida curta (sementes), enquanto as restantes foram obtidos com carvões, em alguns casos de Quercus, o que pode ter dado origem ao designado "old wood effect". Note-se, ainda assim, que as duas datas obtidas para esta estação são estatisticamente semelhantes, não obstante uma ter sido obtida a partir de uma amostra de Quercus e a outra a partir de sementes, pelo que o potencial problema antes mencionado tem de ser relativizado.

Analisemos com pormenor os resultados obtidos, bem como a informação do quadro 7 e fig. 20. Nestes dois últimos encontra-se a calibração das datas convencionais de radiocarbono fazendo uso da curva IntCal 13 (Reimer et al. 2013) e do programa OxCal (Bronk Ramsey 2001). Recorreu-se também à estatística bayesiana construindo-se um modelo de Sequência com duas Fases (Bronk Ramsey 2009), uma englobando as datas dos contextos do Bronze Final e a outra as dos contextos da I Idade do Ferro, o qual apresenta um índice de concordância (Amod) de 107 (bem superior a 60, considerado o valor mínimo aceitável), o que atesta a validade e fiabilidade do modelo utilizado. Este exercício permitiu testar e validar o enquadramento cronológico proposto, para além de ter proporcionado a determinação de fronteiras, nomeadamente as das Fases atrás referidas.

Valorizando, conjuntamente, datas e contextos, teremos de admitir, como possibilidade, que foram distintos e distendidos os tempos de uso e de circulação dessas cerâmicas nesta região do Centro ocidental da Península Ibérica, numa linha de continuidade.

Face aos resultados e sua calibração, a cerâmica de tipo Carambolo poderia ter surgido ainda no séc. XII, em particular na segunda metade, uma vez que consideramos demasiado elevados os valores de CSIC1286, ou no XI a.C., e não ultrapassaria os finais do séc. IX. Estes resultados, quer para o início, quer para os finais, poderão ser considerados algo desajustados ao que poderíamos esperar para a cronologia desta categoria de cerâmica.

Por outro lado, a fronteira definida para a transição cronológica entre os contextos do Bronze Final e os da I Idade do Ferro teria ocorrido na primeira metade do séc. IX, o que também parece ser algo prematuro para a região em análise atendendo ao que se conhece dos resultados disponíveis, criticamente analisados, para o Sudoeste peninsular (Mataloto et al. 2013).

Também comparando os dois blocos, o conjunto do segundo oferece uma maior coesão relativa centrada no séc. IX a.C.

Por outro lado, ainda, deverá sublinhar-se que a definição das designadas cronologias altas e baixas antes mencionadas não teve por base a cronologia do radiocarbono, mas sim a cronologia arqueológica. De resto, o assunto é marginal no livro de Casado Ariza (2015), no qual a cronologia não mereceu atenção idêntica às das outras vertentes analisadas. Só agora essa lacuna está a ser superada, tendo merecido especial atenção em recentíssimo trabalho (Mederos Martín 2017). O 


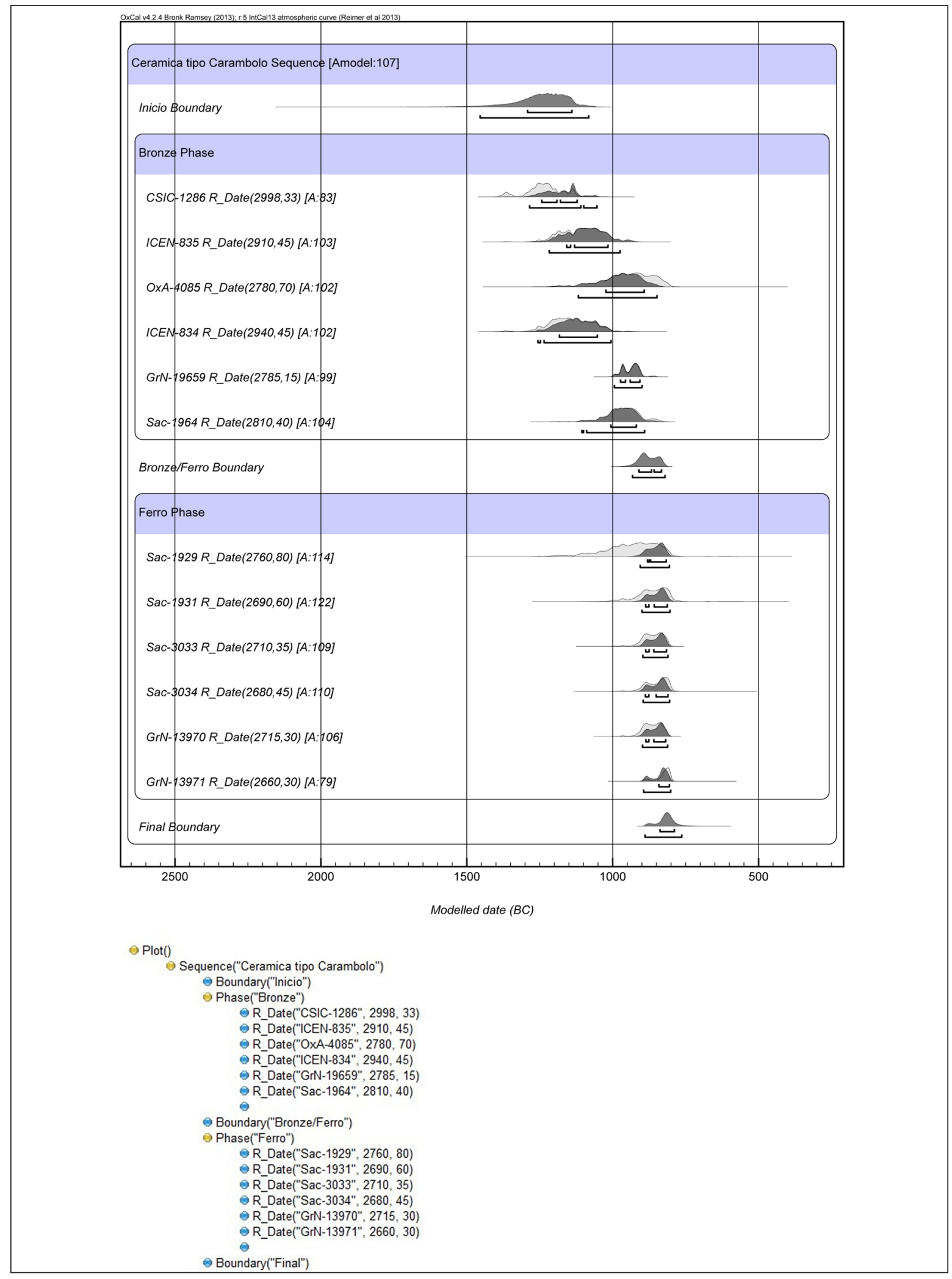

Figura 20. Resultados das análises por Radiocarbono. 
presente contributo, bem como as informações relativas a Alarcos (Ciudad Real), também publicadas há escassos meses (García Huertas e Morales 2017), são fundamentais, justificando que o tema volte a ser discutido oportunamente.

Em suma, é sempre complicado comparar cronologias estritamente arqueológicas com cronologias de radiocarbono. De todo o modo, os resultados obtidos permitiram afinar as coordenadas cronológicas destas cerâmicas. No caso vertente, o séc. IX a.C., concretamente a sua primeira metade, com cerâmicas de tipo Carambolo perfeitamente contextualizadas e datadas, corresponderia à fase de transição cronológica entre os contextos do Bronze Final e os da I Idade do Ferro.

$\mathrm{E}$, independentemente das leituras que a arqueologia permite e que o radiocarbono indica, a amplitude cronológica das cerâmicas de tipo Carambolo não é desmentida nem pelas cronologias relativas nem pelas absolutas. O carácter de excepção destas cerâmicas, por certo utilizadas em ocasiões também excêntricas, inscreve-as no rol daqueles bens que, dizemos, de prestígio e que, por isso mesmo, seriam passíveis de serem transmitidos de geração em geração, também como potenciais relíquias, sem perderem o simbolismo original, ou, tendo-o desfocado, e mesmo perdido, mantiveram-se socialmente activas, recontextualizando-se.

No caso da Beira Interior essas cerâmicas foram manipuladas por comunidades de finais da Idade do Bronze e continuaram a sê-lo num período imediatamente seguinte que, operativamente, podemos designar de inícios ou I Idade do Ferro, ou talvez com maior propriedade de um período de transição, porque as materialidades são, em parte, já outras. Por exemplo, a nível da cerâmica mantêm-se as formas carenadas, numa solução de continuidade, mas introduzem-se inovadoras decorações como a cerâmica 'peinada'. A nível dos metais manipulam-se novos artefactos de inspiração 'tartéssica', como as fíbulas Alcores ou Bencarrón, e já não as de arco multicurvilíneo ou de tipo " $a d o c$ chio". Todavia, o problema da transição do Bronze para o Ferro não é de fácil solução e também não é este o espaço e o momento de o aprofundar.

\section{NOTAS FINAIS}

O texto em apreço constitui a primeira síntese sobre cerâmicas de tipo Carambolo encontradas em território português, síntese essa baseada numa exaustiva abordagem dos dados existentes para uma região específica, a Beira Interior. Futuramente, será desejável explorar outros registos, em concreto os do Sul de Portugal (Alentejo e Algarve) com vista a uma perspectiva mais globalizante, que permitirá identificar afinidades ou especificidades entre ambas as regiões e entre esta região mais ocidental da Península Ibérica e a Andaluzia.

A integração contextual e discussão daqueles dados procurou ser bastante completa, atendendo a múltiplas vertentes, nomeadamente, a questões de índole tecnológica, estilística e simbólica. Também pela primeira vez foi analisada a natureza da pigmentação utilizada e valorizaram-se resultados de 14Carbono na determinação das cronologias desta categoria cerâmica.

Em aberto permanece a origem da produção destas cerâmicas, problema sempre muito delicado na ausência, como é o caso, de informação arqueométrica sobre pastas, fabricos, barreiros. O facto de dois dos fragmentos de Vila do Touro (fig. 7-1, 7-2) serem claramente diferentes dos demais, não significa uma proveniência exógena, mas também não a descarta. $\mathrm{E}$, do mesmo modo, algumas das afinidades que encontramos nos restantes relativamente a determinadas produções de outros tipos cerâmicos que consideramos regionais, não fazem deles produções necessariamente beirãs. Admitindo o carácter exógeno de, pelo menos, algumas, entendemo-lo como mais um elo, a juntar a outros (Vilaça, 2008 b; 2013 a), dos que foram estabelecidos entre a Beira Interior e a Andaluzia, na passagem do II para o I milénios a.C.

Face aos dados compilados, sua análise e discussão, poderemos elaborar o "bilhete de identidade" das cerâmicas de tipo Carambolo da Beira Interior da seguinte forma:

Presença sistematicamente residual nos respectivos contextos de achado, tendo-se contabilizado um número mínimo de 12 recipientes;

Contextos de carácter sempre habitacional, comportando possibilidades de acções além da esfera puramente doméstica e utilitária;

Fabricos manuais, sempre de boa, ou muito boa, qualidade, com pastas depuradas e acabamentos intensamente polidos, brunidos ou engobados;

Formas de pequena, ou muito pequena, capacidade volumétrica, comparáveis a outras formas regionais (carenadas, bicónicas, de perfil em S) e compatíveis com a manipulação de produtos, sólidos ou líquidos, em ínfima quantidade;

Aplicação, após cozedura, de pintura monocromática a vermelho, em regra na superfície exterior, 
excepcionalmente em ambas, quase sempre nos bordos, ou até $2 / 3$ do corpo dos recipientes;

Presença de distintas tonalidades de vermelho, mas sempre uma só em cada exemplar, salvo quando se verifica sobreposição de motivos que resultam na acumulação de camadas de tinta;

Impacto visual muito expressivo resultante do contraste da tonalidade vermelha sobre superfícies escuras (cinzentas-acastanhadas) ou claras (beges-alaranjadas);

Predomínio de motivos geométricos lineares, configurando também triângulos, losangos, rectângulos, escalariformes, métopas, de traçado minucioso e regular, impressionando pela mestria, embora contemplando situações de grau variável; mais raramente, pintura em espalhamento na superfície;

Presença excepcional de pintura sobre prévia decoração de ornatos brunidos, que mimetiza, ou altera;

Pigmentação composta na sua totalidade por ocre vermelho (óxido de ferro do tipo da hematite); certos casos com pigmentação mais alaranjada e em destacamento composta por outros óxidos de ferro que correspondem a produtos de degradação por hidratação e desintegração da pigmentação da respectiva superfície;

Carácter inovador no conceito e técnica da pintura vascular; um "ar de família" das formas e motivos, as e os que também se encontram nas cerâmicas de tipo Baiões e de tipo Lapa do Fumo;

Certa variabilidade cronológica, mas sempre com cronologia alta, num espectro centrado nos sécs. XI-IX a.C.

\section{Agradecimentos}

Expressamos um agradecimento muito especial a António Monge Soares pela sua disponibilidade e prestimosa ajuda no capítulo 4.6., concretamente na calibração das datas e nos exercícios relativos à estatística bayesiana, bem como na elaboração do Quadro 7 e Fig. 25, colaboração que se estendeu à discussão dos resultados obtidos. Eventuais erros são, obviamente, da nossa inteira responsabilidade. Também é devido um agradecimento a António Carlos Valera pela cedência da imagem da figura 8 , bem como a respectiva autorização para a sua publicação, e a Ana Pernas pelas fotos das figuras 11, 12 e 15 .

Agradece-se ainda o acesso ao Laboratório de Análise de Traço e Imagem da Universidade de Coimbra TAIL-UC, financiado no âmbito do QREN-Mais Centro, projecto ICT-2009-02-012-1980 e o financiamento dos Centros UID/FIS/04564/2016 e UID/Multi/00070/2013.

\section{BIBLIOGRAFIA}

Almagro Gorbea, M. (1977): El Bronce Final y el periodo orientalizante en Extremadura. Madrid, Biblioteca Praehistorica Hispana, vol. XIV.

Almagro Gorbea, M. e Martín, A.M. (1994): Castros y Oppida en Extremadura. Compluntum Extra 4, Madrid, Editorial Complutense.

Amores, F. de (1995): "La cerámica pintada estilo Carambolo: una revisión necessária de su cronologia”. in Tartessos. 25 años después 1968-1993. Actas del Congreso Conmemorativo del V Symposium Internacional de Prehistoria Peninsular: 159-178. Biblioteca de Urbanismo y Cultura. Cádiz. Ayuntamiento de Jerez de la Frontera.

Belén, M. e Escacena, J.L. (1997): “Testimonios religiosos de la presencia fenicia en Andalucía ocidental". Spal 6: 103-131. http://dx.doi.org/10.12795/ spal.1997.i6.07

Bendala, M. (1979): "Las más antiguas navegaciones griegas a España y el origen de Tartessos". Archivo Español de Arqueología 52: 33-38.

Benet, N. (1990): "Un vaso pintado y tres dataciones de C-14 procedentes del Cerro de San Pelayo (Martinamor, Salamanca)". Nvmantia III: 77-94.

Blasco Bosqued, M.C. (1980-1981): "Reflexiones sobre la cerámica pintada del bronce final y primera edad del hierro, en la Península Ibérica". Cuadernos de Prehistoria y Arqueologia 7-8: 72-92.

Bronk Ramsey, C. (2001): "Development of the radiocarbon calibration program OxCal". Radiocarbon $43\left(2^{\mathrm{A}}\right): 355-363$.

Bronk Ramsey, C. (2009): "Bayesian analysis of radiocarbon dates". Radiocarbon 51 (1): 337-360.

Buero Martínez, M.S. (1984): "Los motivos naturalistas en la cerámica pintada del Bronce Final del Suroeste Peninsular". Habis 15: 345-364.

Buero Martínez, M.S. (1987): "El Bronce Final y las cerámicas Tipo Carambolo". Revista de Arqueología, año VIII 70: 35-47.

Buero Martínez, M.S. e Fernández Goméz, F. (2010): "La cerámica tipo Carambolo en la Universidad Laboral de Sevilla: problemática del Bronce e del Orientalizante en Andalucía Occidental”. Temas de Estética y Arte XXIV: 40-68.

Campos, J.M. e Alvar, J. (eds.) (2013): Tarteso. El empório del metal. Sevilha, Editorial Almuzara.

Carriazo, J.M. (1969): "El Cerro del Carambolo". Tartessos y sus problemas. V Symposium Internacional de Prehistoria Peninsular, Instituto de Arqueología y Prehistoria. Publicaciones 
Eventuales $n^{\circ} 13:$ 311-340. Barcelona, Universidad de Barcelona.

Carriazo, J.M. (1973): Tartesos y el Carambolo. Investigaciones arqueológicas sobre la protohistoria de la Baja Andalucía. Dirección General de Bellas Artes. Madrid, Ministerio de Educación y Ciencia.

Casado Ariza, M.J. (2003): "Reflexiones sobre la cerámica tipo Carambolo. Un axioma de la Arqueología Protohistórica del Suroeste Andaluz". Spal 12: 283 298. http://dx.doi.org/10.12795/spal.2003.i12.11

Casado Ariza, M.J. (2015): La cerámica con decoración geométrica del Carambolo. Spal Monografías XXI, Sevilla, Editorial Universidad de Sevilla.

Escacena Carrasco, J.L. (2010): "El Carambolo y la construcción de la arqueología tartésica". in Bandera Romero, M. L., Ferrer Albelda, E. (coord.), El Carambolo. 50 años de un tesoro: 99-148. Sevilla, Editorial Universidad de Sevilla.

Fernandes, D. (2016): “O Castro do Cabeço da Argemela (Lavacolhos, Fundão). Uma abordagem à realidade material e o contributo para o seu enquadramento cultural e regional”. in Vilaça, R. (coord.), II Congresso Internacional de Arqueologia da região de Castelo Branco: 201-216. Castelo Branco, Sociedade de Amigos do Museu Francisco Tavares Proença Júnior, RvjEditores.

Fernández Flores, A. e Rodríguez Azogue, A. (2007): Tartessos Desvelado. La Colonización Fenicia del Suroeste Peninsular y el Origen y Ocaso de Tartessos. Sevilla, Editorial Almuzara.

García Huertas, R. e Morales, J. (2017): “El poblado de Alarcos (Ciudad Real) en los inicios del I milenio a.C.: estructuras y materiales cerámicos". Trabajos de Prehistoria 74-1: 108-126. https://doi. org/10.3989/tp.2017.12186

Jones, A. (2007): Memory and Material Culture. Cambridge, Cambridge University Press.

López Jiménez, O. (2003): "Dataciones radiocarbónicas en la Protohistoria del Sudeste de la Meseta Norte. Consideraciones para un trabajo por hacer". Trabajos de Prehistoria 60 (2): 131-142.

Marques, J.N.; Almeida, S.; Ferreira, N. e Vilaça, R. (2011-2012): “O Castro do Cabeço da Argemela (Fundão). Trabalhos desenvolvidos entre 2003 e 2009”. Eburobriga 7: 78-99.

Martin Benito, J. I. e Martin Benito, J. C. (1990): Prehistoria y Romanización de la Tierra de Ciudad Rodrigo. Centro de Estudios Mirobrigenses, Ciudad Rodrigo, Ayuntamiento de Ciudad Rodrigo.

Mataloto, R.; Martins, J.M. e Soares, A.M. (2013): "Cronologia absoluta para o Bronze do Sudoeste.
Periodização, base de dados, tratamento estatístico". Estudos Arqueológicos de Oeiras 20: 303-338.

Mederos Martín, A. (2017): La cronologia de la cerámica pintada monocroma roja tipo Carambolo del Bronce Final IIC-III e inícios de la Edad del Hierro del suroeste de la Península Ibérica (1150-825 a. C.). In Brandherm, D. (ed.), Memento dierum antiquorum... Festschrift für Majolie Lenerz-de Wilde zum 70. Geburtstag. Hagen/Westf, Archaeologia Atlantica, Monograptiar 1, 105-125.

Osório, A.B. (2013): Gestos e materiais: uma abordagem interdisciplinar sobre cerâmicas com decorações brunidas do Bronze Final / I Idade do Ferro. 2 vols., Universidade de Coimbra (dissertação de doutoramento). https://estudogeral.sib.uc.pt/handle/10316/23778

Papadopoulos, J.K.; Vedder, J.F.; Schreiber, T. (1998): "Experimental Archaeology and the Pivoted Multiple Brush". American Journal of Archaeology 102 (3): 507-529.

Ponte, S.; Osório, M. e Vilaça, R. (2017): Duas fíbulas provenientes de Vila do Touro (Sabugal). Estudos Pré-históricos XVII: 135-145.

Reimer, P.J.; Bard, E.; Bayliss, A.; Beck, J.W.; Blackwell, P.G.; Bronk Ramsey, C.; Buck, C.E.; Cheng, H.; Edwards, R.L.; Friedrich, M.; Grootes, P.M.; Guilderson, T.P.; Haflidason, H.; Hajdas, I.; Hatté, C.; Heaton, T.J.; Hoffmann, D.L.; Hogg, A.G.; Hughen, K.A.; Kaiser, K.F.; Kromer, B.; Manning, S.W.; Niu, M.; Reimer, R.W.; Richards, D.A.; Scott, E.M.; Southon, J.R.; Staff, R.A.; Turney, C.S.M. e Van der Plicht, J. (2013): "IntCal13 and Marine13 Radiocarbon Age Calibration Curves, 0-50,000 Years cal BP”, Radiocarbon 55 (4): 1869-1887.

Rodriguez Azogue, A. e Fernández Flores, A. (2005): "El santuario orientalizante del cerro del Carambolo, Camas (Sevilla). Avance de los resultados de la segunda fase de la intervención". in Celestino, S., Jiménez, J. (eds.) El Período Orientalizante. Anejos de Archivo Español de Arqueología XXXV: 863871. Mérida.

Ruiz Mata, D. (1984-1985): "Puntualizaciones sobre la ceramica pintada tartéssica del Bronce Final - estilo Carambolo o Guadalquivir I". Cuadernos de Prehistoria y Arqueología [Homenaje al Prof. Gratiano Nieto] 11-12 (I): 224-243.

Ruiz Mata, D. (1995): "Las cerámicas del Bronce Final. Un suporte tipológico para delimitar el tiempo y el espacio tartesico". in Tartessos. 25 años después 1968-1993. Actas del Congreso Conmemorativo del V Symposium Internacional de Prehistoria 
Peninsular: 265-313. Cádiz (1993), Cádiz, Ayuntamiento de Jerez de la Frontera.

Ruiz Mata, D. e Fernández Jurado, J. (1986): “El yacimiento metalúrgico de época tartesica de San Bartolomé de Almonte (Huelva)". Huelva Arqueológica VIII.

Ruiz-Gálvez Priego, M. (1993): "El ocidente de la Península Ibérica, punto de encuentro entre el Mediterraneo y el Atlántico a fines de la Edad del Bronce". Complutum 4: 41-68.

Soares, A. M. (2005): “Os povoados do Bronze Final do Sudoeste na margem esquerda portuguesa do Guadiana: novos dados sobre a cerâmica de ornatos brunidos". Revista Portuguesa de Arqueologia 8(1): 111-145.

Soares, I. (2016): Espaços de Habitação no Bronze Final: das materialidades às vivências sociais - $\mathrm{O}$ Povoado da Moreirinha, [Mestrado em Arqueologia e Território apresentada à Faculdade de Letras da Universidade de Coimbra].

Torres Ortiz, M. (2002): Tartessos. Madrid, Real Academia de la Historia.

Torres Ortiz, M. (2016): “Algunas consideraciones cronológicas sobre el yacimiento tartésico de El Carambolo". Cadernos do Museu da Lucerna II [Actas da Mesa Redonda Turdetânia e Turdetanos]: 79-96. Castro Verde, Museu da Lucerna - Cortiçol.

Valera, A. C. (2008): “A Quinta das Rosas (Fornos de Algodres): expressão de matrizes prévias do povoamento da Pré-História Recente durante o Bronze final". in III Congresso de Arqueologia de Trás-os-Montes, Alto Douro e Beira Interior vol. I: 136150. Freixo de Numão, Associação Cultural, Desportiva e Recreativa de Freixo de Numão.

Vilaça, R. (1995): Aspectos do Povoamento da Beira Interior (Centro e Sul) nos finais da Idade do Bronze. Trabalhos de Arqueologia 9, Lisboa, IPPAR.

Vilaça, R. (2005): “Entre Douro e Tejo, por terras do interior: o I milénio a. C.". in Lusitanos e Romanos no Nordeste da Lusitânia [Actas das 2. ${ }^{\mathrm{a}} \mathrm{s}$ Jornadas do Património da Beira Interior]: 13-32. Guarda, Centro de Estudos Ibéricos.

Vilaça, R. (2007a): “A Cachouça (Idanha-a-Nova, Castelo Branco). Construção e organização de um caso singular de inícios do I milénio AC’”. in Jorge, S.O. et al. (ed.), A concepção das paisagens e dos espaços na Arqueologia da Península Ibérica. [Actas do IV Congresso de Arqueologia Peninsular]: $67-$ 75. Faro, Centro de Estudos de Património, Faculdade de Ciências Humanas e Sociais da Universidade do Algarve.
Vilaça, R. (2007b): “A Idade do Bronze”. in Rosa, J.M. (coord.), Catálogo. Museu Arqueológico Municipal José Monteiro: 39-43. Fundão, Museu Arqueológico Municipal José Monteiro.

Vilaça, R. (2008a): "The Chalcolithic in Beira Interior (Central Portugal): data and problems". in Bueno-Ramírez, P., Barroso-Bermejo, R., Balbín-Berhmann, R. (eds.), Graphical Markers and Megalith Builders in the International Tagus, Iberian Peninsula: 157-170. BAR International Series 1765. Oxford, Archaeopress.

Vilaça, R. (2008b): "Reflexões em torno da presença mediterrânea no Centro do território português, na charneira do Bronze para o Ferro". in Celestino Pérez, S.; Rafel, N.; Armada, X.-L. (eds.), Contacto cultural entre el Mediterráneo y el Atlántico (siglos XII-VIII ANE): La Precolonización a debate: $371-$ 400. Madrid, Escuela Española de Historia y Arqueología de Roma del CSIC, Série Arqueológica.

Vilaça, R. (2013a): "Late Bronze Age: Mediterranean impacts in the Western End of the Iberian Peninsula (actions and reactions)". in Aubet, E. e Pau, S. (coord.), Interacción Social y Comercio en la Antesala del Colonialismo: Los Metales como Protagonistas. Actas del Seminario Internacional, Cuadernos de Arqueología Mediterránea 21: 13-30. Barcelona, Publicaciones del Laboratorio de Arqueología de la Universidad Pompeu Fabra.

Vilaça, R. (2013b): "L'arrivée des premiers fers dans l'Occident atlantique". Dossier les transferts de technologie au premier millénaire av. j.-c., Mélanges de la Casa de Velázquez. Nouvelle série 43 (1): 39 64. Madrid, Casa de Velázquez.

Vilaça, R. (2013c): “O povoamento da Beira Interior durante o Bronze Final: evidências, interação e simbolismos". Estudos Arqueológicos de Oeiras 20: 191-220.

Vilaça, R. e Basílio, L. (2000): “Contributo para a caracterização arqueológica da I Idade do Ferro da Beira Interior: cerâmicas a torno da Cachouça (Idanha-a-Nova)". Al-madan II série 9: 39-47.

Vilaça, R.; Beck, C. e Stout, E. (2002): "Provenience analysis of prehistoric amber artefacts in Portugal". Madrider Mitteilungen 43: 61-78.

Vilaça, R.; Almeida, S.; Bottaini, C.; Marques, J.N. e Montero-Ruiz, I. (2011): "Metalurgia do Castro do Cabeço da Argemela (Fundão): formas, conteúdos, produções e contextos". in Martins, C.; Bettencourt, A.; Martins, J.; Carvalho, J. (coord.), Povoamento e Exploração de Recursos Mineiros na Europa Atlântica Ocidental: 427-451. Braga, CITCEM - Centro 
de Investigação Transdisciplinar "Cultura, Espaço e Memória".

Vilaça, R.; Jiménez Ávila, J. e Galán Domingo, E. (2012): "El poblado de Los Concejiles (Lobón, Badajoz) en el contexto del Bronce Final del Guadiana Medio". in Jiménez Ávila, J. (ed.), Ana II El río Guadiana en el Bronce Final, Anejos de AEspa LXII: 125-165. Mérida, Instituto de Arqueología - Mérida, CSIC.
Vilaça, R., Rosa, J. M., Bizarro, J., Pires, H. e Baptista, P. (2016): "New stele. New story. A Late Bronze Age reference in Cova da Beira (Telhado, Fundão, Portugal)". Poster apresentado no International Symposium Images in stone in Prehistory and Protohistory (Braga, 2016). Braga, CITCEM - Centro de Investigação Transdisciplinar "Cultura, Espaço e Memória". 